\title{
Alethopteris and Neuralethopteris from the lower Westphalian (Middle Pennsylvanian) of Nova Scotia and New Brunswick, Maritime Provinces, Canada
}

\author{
CARMen Álvarez-VÁzQuez \\ Centro Paleobotánico, Real Jardín Botánico de Córdoba, Avenida de Linneo, s/n, 14004 Córdoba, Spain \\ paleo.calvarez@jardinbotanicodecordoba.com
}

Date received: 19 January 2020 g Date accepted: 24 March 2020

\begin{abstract}
A systematic revision of Alethopteris and Neuralethopteris from upper Namurian and lower Westphalian (Middle Pennsylvanian) strata of Nova Scotia and New Brunswick, eastern Canada, has demonstrated the presence of eight species: Alethopteris bertrandii, Alethopteris decurrens, Alethopteris cf. havlenae, Alethopteris urophylla, Alethopteris cf. valida, Neuralethopteris pocahontas, Neuralethopteris schlehanii and Neuralethopteris smithsii. Restudy of the Canadian material has led to new illustrations, observations and refined descriptions of these species. Detailed synonymies focus on records from Canada and the United States. As with other groups reviewed in earlier articles in this series, it is clear that insufficient attention has been paid to material reposited in Canadian institutions in the European literature. The present study emphasizes the similarity of the North American flora with that of western Europe, especially through the synonymies.
\end{abstract}

\section{RÉSUMÉ}

Une révision systématique des Alethopteris et Neuralethopteris des strates du Namurien supérieur et du Westphalien inférieur (Pennsylvanien moyen) de la Nouvelle-Écosse et du Nouveau-Brunswick, dans l'est du Canada, a démontré la présence de huit espèces : Alethopteris bertrandii, Alethopteris decurrens, Alethopteris cf. havlenae, Alethopteris urophylla, Alethopteris cf. valida, Neuralethopteris pocahontas, Neuralethopteris schlehanii et Neuralethopteris smithsii. L'étude du matériel canadien a mené à de nouvelles illustrations, observations et descriptions raffinées de ces espèces. Les listes détaillées de synonymes se concentrent sur les documents du Canada et des États-Unis. Comme pour les autres groupes examinés dans les articles précédents de cette série, il est clair qu'une attention insuffisante a été accordée aux documents déposés dans les institutions canadiennes dans la littérature européenne. La présente étude souligne la similitude de la flore nord-américaine avec celle de l'Europe occidentale, notamment à travers les synonymies.

[Traduit par la redaction]

\section{INTRODUCTION}

This study is the ninth part of a revision of upper Namurian and lower Westphalian flora of Nova Scotia and New Brunswick, Maritime Provinces, Canada, begun in 2000 by R.H. Wagner at the request of John Utting, then of the Geological Survey of Canada. The reports began with a series of short papers (Wagner 2001, 2005a, b, 2008; Wagner and Álvarez-Vázquez 2008), and continued with more extensive contributions on lycopsids (Álvarez-Vázquez and Wagner 2014), the sphenopsid genera Annularia and Asterophyllites (Álvarez-Vázquez and Wagner 2017), and ferns (ÁlvarezVázquez 2019). The revision is based on examination of specimens and a critical re-evaluation of illustrations and descriptions in publications by Dawson $(1862,1863,1868$, 1871), Matthew (1910), Stopes (1914) and Bell (1938, 1944, 1962, 1966).

The specimens involved are mainly preserved as impressions. Most are reposited in the collections of the Geological Survey of Canada (GSC) in Ottawa (catalogue numbers preceded by GSC). They are mostly fragmentary specimens collected in the course of field mapping by Geological Survey of Canada personnel at the end of the Nineteenth Century and the beginning of the Twentieth Century; the collection was initially studied by Walter A. Bell in the mid-Twentieth Century. Bell's (1944) memoir is very comprehensive, but his use of photographs commonly at natural size makes it often difficult to see the details necessary for an accurate 
identification - perhaps one of the reasons why Bell's work has not been used extensively. In addition to the collections already mentioned, several specimens from the New Brunswick Museum at Saint John, New Brunswick (14 specimens designated with catalogue numbers with the prefix NBMG), and the Donald Reid Collection, Joggins Fossil Institute, Joggins, Nova Scotia (four specimens designated with catalogue numbers with the prefix DRC), have also been reviewed for the present study.

For more complete information about the localities associated with the GSC material, the reader is referred to the memoirs published by Bell (1938, pp. 108-115; 1944, pp. 111-118).

\section{SYSTEMATIC PALEOBOTANY}

As in previous papers in this series (Álvarez-Vázquez and Wagner 2014; Álvarez-Vázquez and Wagner 2017; Álvarez-Vázquez 2019), selective synonymy lists refer mainly to the published records from North America. Only the most significant records from elsewhere and specimens in the collections of the Paleobotanical Centre, Botanical Garden of Córdoba, Spain, are cited where required for a better understanding of the revised taxa. The synonymy lists are thus incomplete, but all old and new synonyms accepted in this study are included. The reader is referred to the Fossilium Catalogus Plantae (Jongmans 1957; Jongmans and Dijkstra 1961; Dijkstra and Amerom 1981, 1983) for additional, but uncritical, records.

Annotations in the synonymy lists are as follows: ${ }^{*}=$ protologue; $\$=$ first publication of currently accepted combination; $\mathrm{T}=$ other illustrations of the holotype; ? = affinity questionable due to poor illustration or preservation; cf. $($ confer $)=$ compare; $p$ (pars) $=$ only part of the specimens published belong to the species; $\mathrm{v}$ (vide) $=$ the author has seen the specimen(s); $\mathrm{k}=$ reference includes cuticular evidence; acc. to $=$ according to.

Also provided are: descriptions and/or comparisons and remarks on published specimens; stratigraphic occurrences in accordance with the western European regional chronostratigraphic subdivisions of the Pennsylvanian Subsystem; and geographic distribution of taxa in Canada and the USA.

Names of taxa at generic and lower rank cited herein are listed with full authorship in the Appendix.

\section{Order Medullosales Corsin 1960}

Family Alethopteridaceae Corsin 1960

emend. Cleal and Shute 2003

Genus Alethopteris Sternberg 1825

emend. Zodrow and Cleal 1998

1825 Alethopteris Sternberg, p. 21.

1910 Johannophyton Matthew, p. 83-84 (acc. to Stopes 1914).

1912 Alethopteris Sternberg; Franke, p. 1-13.

1955 Alethopteris Sternberg; Crookall, p. 6-8.
1957 Alethopteris Sternberg; Jongmans, p. 89-90 (including synonymy).

1961 Alethopteris Sternberg; Buisine, p. 65-74 (including synonymy).

1968 Alethopteris Sternberg; Wagner, p. 22-30 (including synonymy).

1996 Alethopteris Sternberg; Šimůnek, p. 6-7.

1998 Alethopteris Sternberg; Zodrow and Cleal, p. 70-71 (emended diagnosis).

Type. Alethopteris lonchitica Schlotheim 1820 ex Sternberg 1825.

Diagnosis. Bipartite fronds. Primary pinna tripinnate, with no intercalated pinnules or pinnae on the primary or secondary rachises, which are usually striate. Pinnules asymmetric, fused at the base, decurrent on the basiscopic side, straight or slightly constricted on the acroscopic side. Pinnule lamina thick, giving a vaulted aspect to the pinnules. Venation characterized by a well-marked and strongly decurrent midvein and numerous, non-anastomosed laterals that meet the pinnule margin at about right-angles or somewhat obliquely. Lateral veins fork at irregular intervals, mostly once, sometimes by a tripartite division, and occasionally each fork divides again. (Shortened from the emended diagnosis by Zodrow and Cleal 1998 - cuticular characteristics excluded.).

Remarks. Although also recorded in upper Mississippian strata and extending into the lowermost Permian, Alethopteris is essentially a Pennsylvanian genus. The selection of the type as Alethopteris lonchitica has given rise to taxonomic problems, as discussed by Wagner and Álvarez-Vázquez (2008). Extensive synonymies can be found in Jongmans (1957), Buisine (1961) and Wagner (1968).

Alethopteris is widespread and fairly closely circumscribed morphologically, forming a natural grouping with Lonchopteris (Brongniart 1828) and Lonchopteridium (see Gothan 1909, who established Lonchopteridium as a "subgroup" of Lonchopteris; and Guthörl 1958 who raised Lonchopteridium to generic rank). The three genera have pinnules of similar shape and size, with confluent, decurrent bases and are separated by different types of venation: free lateral veins in Alethopteris, pseudoanastomosed lateral veins in Lonchopteridium, and fully anastomosed veins forming polygonal meshes in Lonchopteris. Available evidence on reproductive organs suggests that Neuralethopteris, which has pinnules that have stalked to slightly decurrent base and free veins, also belongs to the same natural grouping (Buisine 1961; Goubet et al. 2000).

The size of Alethopteris fronds seems to have been very substantial, based on the 1.2-m-long fragment recorded by Laveine (1986), who calculated a total frond length of more than $7 \mathrm{~m}$. Laveine et al. (1992) figured and described a probably bipartite frond with quadripinnate primary pinnae and without intercalary pinna elements on the rachises. Ovules are of the Trigonocarpus type (when preserved as casts or 
adpressions) and the Pachytesta-type (when anatomically preserved); and pollen producing organs are of the Whittleseya type (when adpressions) and the Bernaultia-type (when anatomically preserved).

\section{Alethopteris bertrandii Bouroz 1956}

(Figs. 1a-b; 2a-d)

p $\quad 1871$ Alethopteris discrepans Dawson, p. 54, pl. XVIII, fig. 203; pl. XVIII, figs. 204-204c; non pl. XVIII, fig. 205 (this schematic figure cannot be properly judged, but it is comparable with both Alethopteris decurrens and Alethopteris urophylla).

? 1879-80 Alethopteris lonchitica Schlotheim ex Sternberg; Lesquereux, p. 177-179, pl. XXVIII, figs. 7-7a (included in Alethopteris lancifolia by Wagner and Álvarez-Vázquez 2008).

p 1910 Johannophyton discrepans Matthew, p. 83-85, pl. II, fig. 7 (included in Alethopteris lancifolia by Wagner 2005b); pl. III, fig. 1 (same as Dawson 1871, pl. XVIII, fig. 203); pl. III, figs. 2, 4-6 (same as Dawson 1871, pl. XVIII, figs. 204-204c - Alethopteris urophylla acc. to Wagner and Álvarez-Vázquez 2008); non pl. II, figs. 8-9 (sporangia); non pl. III, fig. 3 (resemble Alethopteris urophylla); non pl. III, figs. 7, 9 (= Alehtopteris urophylla); non pl. III, figs. 8, 10 (sporangia).

v p 1914 Alethopteris lonchitica (= Alethopteris discrepans) Schlotheim ex Sternberg; Stopes, p. 47-53, pl. XIII, fig. 31 (photographic illustration of Dawson 1871, pl. XVIII, fig. 204 - wrongly cited as fig. 240); pl. XIII, fig. 32 (poorly illustrated); non, pl. XII, fig. 30 (= Alethopteris urophylla); non pl. XIII, fig. 33 (fragmentary specimen, here included in Alethopteris decurrens); non pl. XVIII, fig. 46 (sporangia and pinnule fragments that may belong either to Alethopteris sp. or Neuralethopteris sp.); non pl. XXII, fig. 57A (= Alethopteris sp. indet. acc. to Wagner and Álvarez-Vázquez 2008); non text-figs. 8A-C (diagrammatic drawings - Alethopteris urophylla).

p 1953 Alethopteris lonchitica Schlotheim ex Sternberg; Gothan, Taf. 4, fig. 1 (as Alethopteris lonchitica forma Serli in the plate); non p. 16-18, Taf. 4, figs. 2, 5 (= Alethopteris urophylla), fig. 3 (= Alethopteris urophylla?), fig. 4 (= Alethopteris westphalensis acc. to Wagner 1968); non Taf. 5, figs. 1, 4, 5 (= Alethopteris urophylla), figs. 2-2a (comparable with Alethopteris westphalensis acc. to Wagner and Álvarez-Vázquez 2008), fig. 3 (= Alethopteris pseudograndinioides acc. to Wagner and Álvarez-Vázquez 2008); non Taf. 6, fig. 1 (comparable with Alethopteris westphalensis acc. to Wagner 1968), figs. 2-4 (= Alethopteris urophylla).

p 1955 Alethopteris lonchitica Schlotheim ex Sternberg; Crookall, pl. V, fig. 1; non p. 22-26, pl. V, fig. 2 (= Alethopteris urophylla); non pl. X, figs. 1, 3 (= Alethopteris urophylla); non textfig. 7 (reproduction of Schlotheims's original illustration); non text-fig. $14 \mathrm{H}$ (venation drawing).

* 1956 Alethopteris Bertrandi Bouroz; p. 137-141, pl. VII, figs. A-C; pl VIII, figs. D-F; pl. IX, fig. G.

T 1961 Alethopteris Bertrandi Bouroz; Buisine, $\mathrm{p}$. 130-137, pl. XXVIII, fig. 1; pl. XXIX, fig. 1 (same as Bouroz 1956, pl. VII, fig. A), figs. 1a-1c (enlargements); pl. XXX, fig. 1 (same as Bouroz 1956, pl. VIII, fig. D), figs. la-1b; pl. XXXI, fig. 1 (same as Bouroz 1956, pl. IX, fig. G), figs. 2-2a; pl. XXXII, figs. 1-1a, figs. 2-2a (same as Bouroz 1956, pl. VII, fig. B); text-fig. 12 (drawing).

* 1961 Alethopteris lancifolia Wagner, p. 6-8, pl. 1, figs. 1-4; pl. 2, figs. 5-8; pl. 3, figs. 9-11; pl. 4, figs. 12-13a.

1983 Alethopteris lonchitica Schlotheim ex Sternberg; Josten, p. 128-129, Taf. 47, figs. 1-1a; text-fig. 91 (venation drawing).

1987 Alethopteris discrepens latus Matthew; Miller, p. 20, fig. 19 (photographic illustration of Matthew 1910, pl. II, fig. 7).

1988 Alethopteris discrepens latus Matthew; Miller and Buhay, p. 223, fig. 5 (same as Miller 1987, fig. 19).

v 2005b Alethopteris lancifolia Wagner; Wagner, p. 16-18, figs. 1a-b (partial counterpart of the specimen figured by Matthew 1910, pl. II, fig. 7).

2006 Alethopteris decurrens (Artis) Frech; Calder et al., p. 180, 183, fig. 11A (two specimens, part and partial counterpart; the one on the lower part refigured herein as Figs. 1a-b).

Description. Frond at least bipinnate. Penultimate order rachis straight, longitudinally striate, about $1 \mathrm{~mm}$ wide. Last order pinnae closely spaced or slightly overlapping laterally, apparently subrectangular, with subparallel margins tapering in the distal part. Dimensions: $80 \mathrm{~mm}$ long (incomplete) and $30-100 \mathrm{~mm}$ wide. Last order rachis straight, longitudinally striate, ca. $0.5-0.75 \mathrm{~mm}$ wide. Pinnules well spaced, inserted at $45-80^{\circ}$, united by a narrow band of lamina; they are large, sturdy, parallel-sided to slightly biconvex, with bluntly acuminate to obtuse apex, constricted acroscopic side and decurrent basiscopic. Dimensions: more than $55 \mathrm{~mm}$ length (longest, incomplete, pinnules) and $8-12 \mathrm{~mm}$ width; 12-18 $\mathrm{mm}$ length and 3-4 $\mathrm{mm}$ width the smaller. Lamina thick, vaulted. Venation clearly marked. Midrib straight, well marked and deeply imprinted in the lamina, extending 


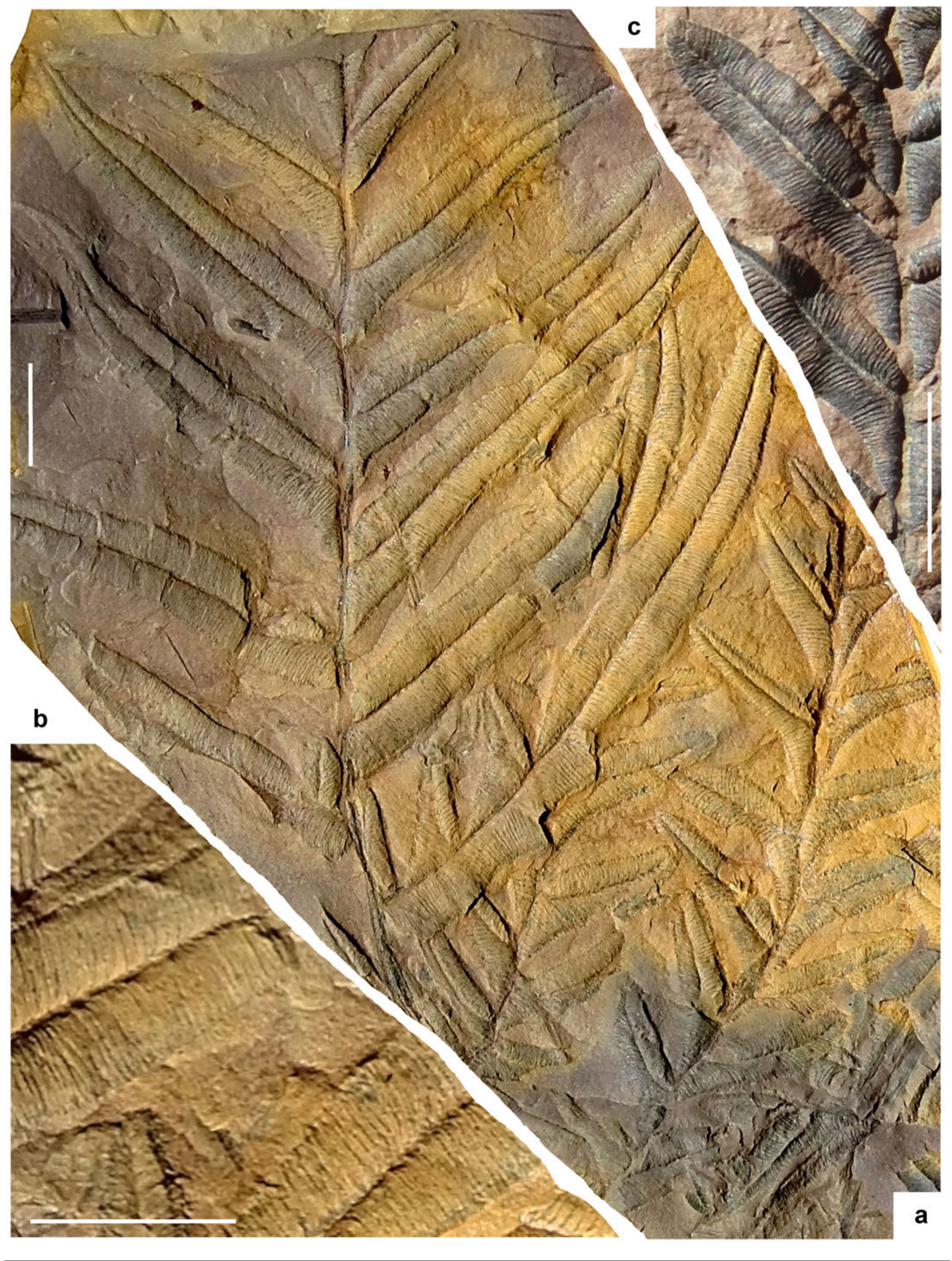


to the apical part. Lateral veins relatively thin, close, subparallel and nearly perpendicular to both the midrib and pinnule margins, single or once forked near the midrib or at one third of the width. Subsidiary veins simple or, occasionally, once forked. Vein density $=36-40$ per centimetre on the pinnule border.

Remarks. I include in Alethopteris bertrandii several specimens from Nova Scotia and New Brunswick previously figured as Alethopteris discrepans, Alethopteris lancifolia and Alethopteris decurrens.

Matthew (1910) referred Dawson's (1871) illustration of Alethopteris discrepans to the new genus Johannophyton on the basis of associated seed capsules (Sporangites acuminatus) (note that Dawson's "true" Pecopteris discrepans is synonymous with Alethopteris urophylla - see below). However, a direct connection between pinnae and seeds is nowhere visible, and Stopes (1914) and Bell (1944) rightly synonymized Johannophyton with Alethopteris. Together with new illustrations of the seeds, Matthew (1910) refigured Dawson's (1871) original illustrations, adding drawings of additional specimens, including a pinna fragment with large pinnules showing a dense venation (Matthew 1910, pl. II, fig. 7). A photograph of this specimen was published by Miller (1987) and Miller and Buhay (1988) as Alethopteris discrepens (sic) latus Matthew, a manuscript name that appeared on the specimen label. The partial counterpart of this specimen was figured as Alethopteris lancifolia by Wagner (2005b).

Alethopteris lancifolia was described by Wagner (1961) from upper Langsettian strata from the Limburg coalfield, Netherlands. Although Wagner (2005b) noted that the Canadian specimens are more ribbon-shaped and the pinnules are somewhat larger, he assumed that this material was at one extreme of a range of variation of Alethopteris lancifolia. I herein regard Alethopteris lancifolia as a later taxonomic synonym of Alethopteris bertrandii, a species that Wagner apparently overlooked.

Comparisons. Alethopteris bertrandii is an easily recognizable species due to its large, sturdy, broadly lanceolate pinnules united by a narrow band of lamina. Only Alethopteris jankii shows pinnules with similar morphology, but they are even larger, up to $120 \mathrm{~mm}$ long, and have a more rounded apex. In addition, vein density is lower, ca. 25-30 veins per centimetre. Alethopteris jankii is, like Alethopteris bertrandii, a rarely cited species. However, I think that there are some other examples in the literature that should be included in it: e.g., two of the six specimens figured by Wittry (2006, figs $1,5)$ as Alethopteris serlii from Mazon Creek. Lastly, Alethopteris urophylla, the most abundant and widespread species of Alethopteris in the Maritime Provinces (see below), possesses shorter pinnules with a considerable higher vein density, ca. $48-55$ veins per centimetre, and it rarely shows unforked lateral veins.

Stratigraphic and geographic distribution. Alethopteris bertrandii has not been cited as such outside its type area, the Nord/Pas-de-Calais basin, France. I have tried here to compose a complete synonymy list. The type material is from lower Westphalian C (Bolsovian) strata. The type material of the synonymous Alethopteris lancifolia is from upper Westphalian A (Langsettian) strata of the South Limburg Coalfield in the Netherlands. Crookall's (1955) specimen, figured as Alethopteris lonchitica, originated from lower Duckmantian strata of the Yorkshire Coalfield, England; the specimen figured by Josten (1983) came from upper Namurian B strata of the Ruhr basin, Germany; and that published by Gothan (1953) came from an indeterminate locality in the Westphalian of the same basin.

Occurrence in the Maritime Provinces, Canada. Donald Reid collection, Joggins, Nova Scotia (1999): DRC997-72 (here Figs. 1a-b - previously figured by Calder et al. 2006 as Alethopteris decurrens). Fern Ledges, New BRUNSwICK: locality 135 (two pieces without catalogue number - together with Psygmophyllum sp.); locality 351 (one piece without catalogue number). New Brunswick Museum COLLECTION: NBMG 3397 (specimen figured by Matthew 1910 as Johannophyton discrepans; as Alethopteris discrepens latus by Miller 1987 and Miller and Buhay 1988; and as Alethopteris lancifolia by Wagner 2005b). FerN Ledges, New Brunswick: Stopes (1914): McGill UNIVERSITY COLLECTION 3314 (photographic illustration of Daw-son 1871, pl. XVIII, fig. 204).

Occurrence in the United States. Pennsylvania: Lesquereux (1879-1980).

\section{Alethopteris decurrens (Artis 1825) Frech 1880}

(Figs. 3a-f, 4d-e)

* $1825 \quad$ Filicites decurrens Artis, pl. xxi.

* 1833 Pecopteris Mantelli Brongniart, p. 278-279, pl. 83, figs. 3-4 (acc. to Zeiller 1888).

* $1876 \quad$ Alethopteris gracillima Boulay, p. 33-34, pl. II, fig. 5 (acc. to Zeiller 1888).

Figure 1 (previous page). (a) Alethopteris bertrandii. DRC-997-72. Sideritized specimen. It resembles those figured by Bouroz (1956, pl. VII, fig. A) and Buisine (1961, pl. XXIX, fig. 1). Note the apical parts of the penultimate order pinna with large, elongated pinnules replacing the ultimate order pinnae of the most proximal part. Previously figured as Alethopteris decurrens by Calder et al. (2006, fig. 11A). Origin: Joggins section (Donald Reid Collection). (b) Enlargement of Fig. 1a showing the vein pattern. (c) DRC-149-99. Alethopteris urophylla. Venation details of another sideritized specimen, illustrated for shape and size comparison. Note the small size of pinnules. Origin: Joggins section (Donald Reid Collection). Repository: Joggins Fossil Centre, Joggins, Nova Scotia. Scale bar $=1 \mathrm{~cm}$. 

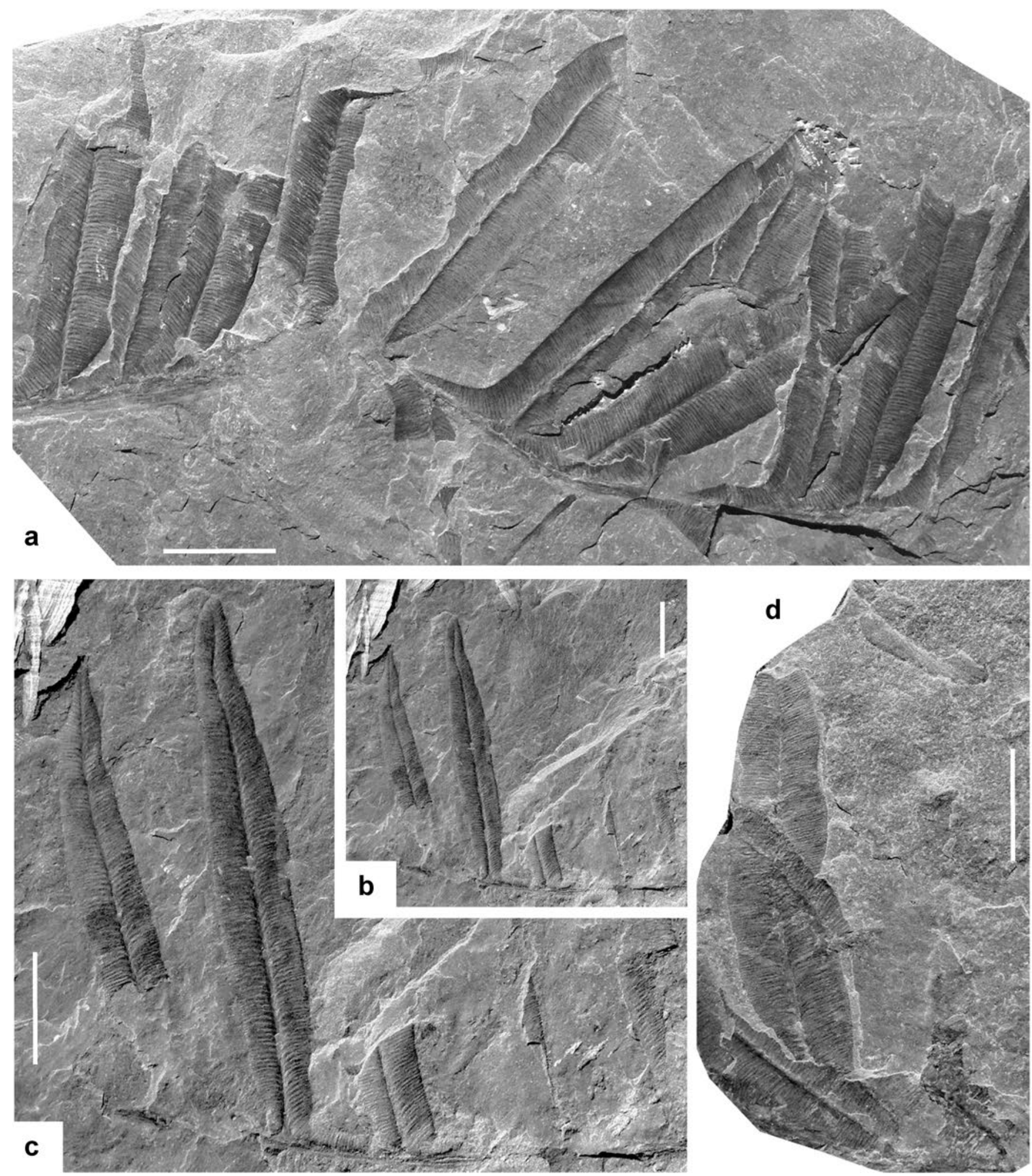

Figure 2. (a) Alethopteris bertrandii. Specimen without catalogue number showing the large, sturdy, slightly biconvex pinnules united by a narrow band of lamina and the constricted acroscopic side and decurrent basiscopic. Origin: Fern Ledges, Saint John, New Brunswick (locality 135). (b) Alethopteris bertrandii. Specimen without catalogue number. Note the vaulted lamina which makes the pinnules look narrower, and the straight midrib, well-marked and deeply imprinted in the lamina, extending to the apical part. Origin: same as for Fig. 2a (locality 135) (c) Enlargement of Fig. 2b showing the subparallel lateral veins that are nearly perpendicular to both the midrib and pinnule margins. (d) Alethopteris bertrandii. Specimen without catalogue number. Origin: Fern Ledges, Saint John, New Brunswick (locality 351). Repository: Geological Survey of Canada, Ottawa. Scale bar $=1 \mathrm{~cm}$. 
$\$ 1880$ Alethopteris decurrens (Artis) Frech, Taf. 1a, fig. 3.

1886-88 Alethopteris decurrens (Artis) Frech; Zeiller, p. 221-224, pl. XXXIV, figs. 2-3; pl. XXXV, fig. 1; pl. XXXVI, figs. 3-4.

v p $1914 \quad$ Alethopteris lonchitica (= Alethopteris discrepans) Schlotheim ex Sternberg; Stopes, pl. XIII, fig. 33 (fragmentary); non p. 47-53, pl. XII, fig. 30 (=Alethopteris urophylla); non pl. XIII, fig. 31 (= Alethopteris bertrandii same as Dawson 1871, pl. XVIII, fig. 204); non pl. XIII, fig. 32 (= Alethopteris bertrandii); non pl. XVIII, fig. 46 (sporangia and pinnule fragments that may belong to either Alethopteris sp. or Neuralethopteris sp.); non pl. XXII, fig. 57A (= Alethopteris sp. indet. acc. to Wagner and Álvarez-Vázquez 2008); non text-figs. 8A-C (diagrammatic drawings of Alethopteris urophylla).

? $1934 \quad$ Alethopteris decurrens (Artis) Frech; Arnold, p. 195, pl. II, figs. 1, 3, 7.

* 1938 Alethopteris scalariformis Bell, p. 69-70, pl. LXII, fig. 5; pl. LXV, figs. 4-7; pl. LXVI, fig. 3 (acc. to Crookall 1955).

v 1944 Alethopteris decurrens (Artis) Frech; Bell, p. 87, pl. XL, fig. 1; pl. XLI, figs. 2-3; pl. XLII, fig. 5; pl. XLV, figs. 5-6.

? 1949 Alethopteris decurrens (Artis) Frech; Arnold, pl. XIX, fig. 4, fig. 7 (same as Arnold 1934, pl. II, fig. 7) (difficult to judge from the illustration - the fragmentary specimens also resemble Alethopteris urophylla).

* 1952a-53 Alethopteris tectensis Stockmans and Willière, p. 241, pl. LVI, figs. 8-8a (the single fragment figured and described by Stockmans and Willière shows the characteristic pinnules of Alethopteris decurrens: flexible, narrow, parallel-sided, decurrent and slightly contracted at the acroscopic side).

* 1952a-53 Alethopteris Edwardsi Stockmans and Willière, p. 240, pl. LVI, figs. 9-9a (the only fragmentary figured specimen came from the same locality as that described as Alethopteris tectensis).

T 1955 Alethopteris decurrens (Artis) Frech; Crookall, p. 26-29 (including synonymy and a reproduction of Artis's illustration), pl. II, figs. 1-3a; pl. VI, figs. 3-3a.

1955 Alethopteris decurrens var. gracillima Crookall, p. 29-30, pl. II, figs. 4-7; text-fig. 9 (reproduction of Boulay's 1876 holotype of Alethopteris gracillima).

1957 Alethopteris decurrens (Artis) Frech; Janssen, p. 144, fig. 130.

1961 Alethopteris decurrens (Artis) Frech; Buisine, p. 155-167 (including synonymy), pl. XLI, figs. 1-1c; pl. XLII, figs. 1-3a; pl. XLIII, figs. 1-2a; pl. XLIV, figs. 1-5; text-figs. 14a-c.

1964 Alethopteris decurrens (Artis) Frech; Read and Mamay, p. 7, pl. 5, fig. 4.

1966 Alethopteris decurrens (Artis) Frech; Bell, p. 10, pl. IV, fig. 4 .

1968 Alethopteris decurrens (Artis) Frech; Basson, p. 69-70, pl. 12, fig. 1 (figures poor).

? 1976 Alethopteris decurrens (Artis) Frech; Gillespie and Pfefferkorn, pl. I, fig. H (also resembles Alethopteris urophylla).

? 1977 Alethopteris decurrens (Artis) Frech; Pfefferkorn and Gillespie, pl. 2, fig. Q (same as Gillespie and Pfefferkorn 1976, pl. I, fig. H).

? 1978 Alethopteris decurrens (Artis) Frech; Gillespie et al., p. 98, pl. 36, fig. 1 (probably correctly identified, but lacking detail of venation).

1984 Alethopteris decurrens (Artis) Frech; Jennings, p. 307, pl. 4, fig. 2.

1985 Alethopteris decurrens (Artis) Frech; Gillespie and Rheams, pl. II, fig. 3 (figures poor).

? 1996 Alethopteris decurrens (Artis) Frech; Cross et al., p. 412, fig. 23-21.2 (difficult to judge also resembles Alethopteris urophylla).

k 1996 Alethopteris decurrens (Artis) Frech; Šimůnek, p. 7-8, pl. II, figs. 1-7; pl. III, figs. 1-2, figs. 3-9 (cuticles); pl. IV, figs. 1-3 (cuticles); text-figs. 4-7.

2014 Alethopteris decurrens (Artis) Frech; Bashforth et al., p. 247, pl. III, fig. 10.

Excludenda:

1963 Alethopteris decurrens (Artis) Frech; Wood, p. 48-49, pl. 5, fig. 9 (= Alethopteris urophylla).

1982 Alethopteris decurrens (Artis) Frech; Oleksyshyn, p. 94-95, figs. 19B, C (resembles Alethopteris missouriensis).

2002 Alethopteris decurrens (Artis) Frech; Blake et al., p. 264, 268, 291, pl. XVIII, fig. 2 (= Alethopteris urophylla acc. to Wagner and Álvarez-Vázquez 2008).

2006 Alethopteris decurrens (Artis) Frech; Calder et al., p. 180, 183, fig. 11A (= Alethopteris bertrandii - see above).

Description. Frond at least bipinnate. Penultimate order rachis straight, longitudinally striate, ca. $0.5-0.75 \mathrm{~mm}$ wide. Last order pinnae closely spaced or slightly touching laterally, elongate, with subparallel margins tapering in the distal part to form an acute angle; apical pinnule well-individualized, elongate, parallel-sided, with a sharply pointed apex, up to $19 \mathrm{~mm}$ in length. Dimensions: $60 \mathrm{~mm}$ long (incomplete) and 10-40 mm wide. Last order rachis straight, longitudinally striate, ca. $0.25-0.50 \mathrm{~mm}$ wide. Pinnules set well apart (3-5 mm), oblique to the rachis $\left(30-60^{\circ}\right)$, decurrent, confluent, slightly contracted at the acroscopic side. Variation in length is considerable, but the approximate width 

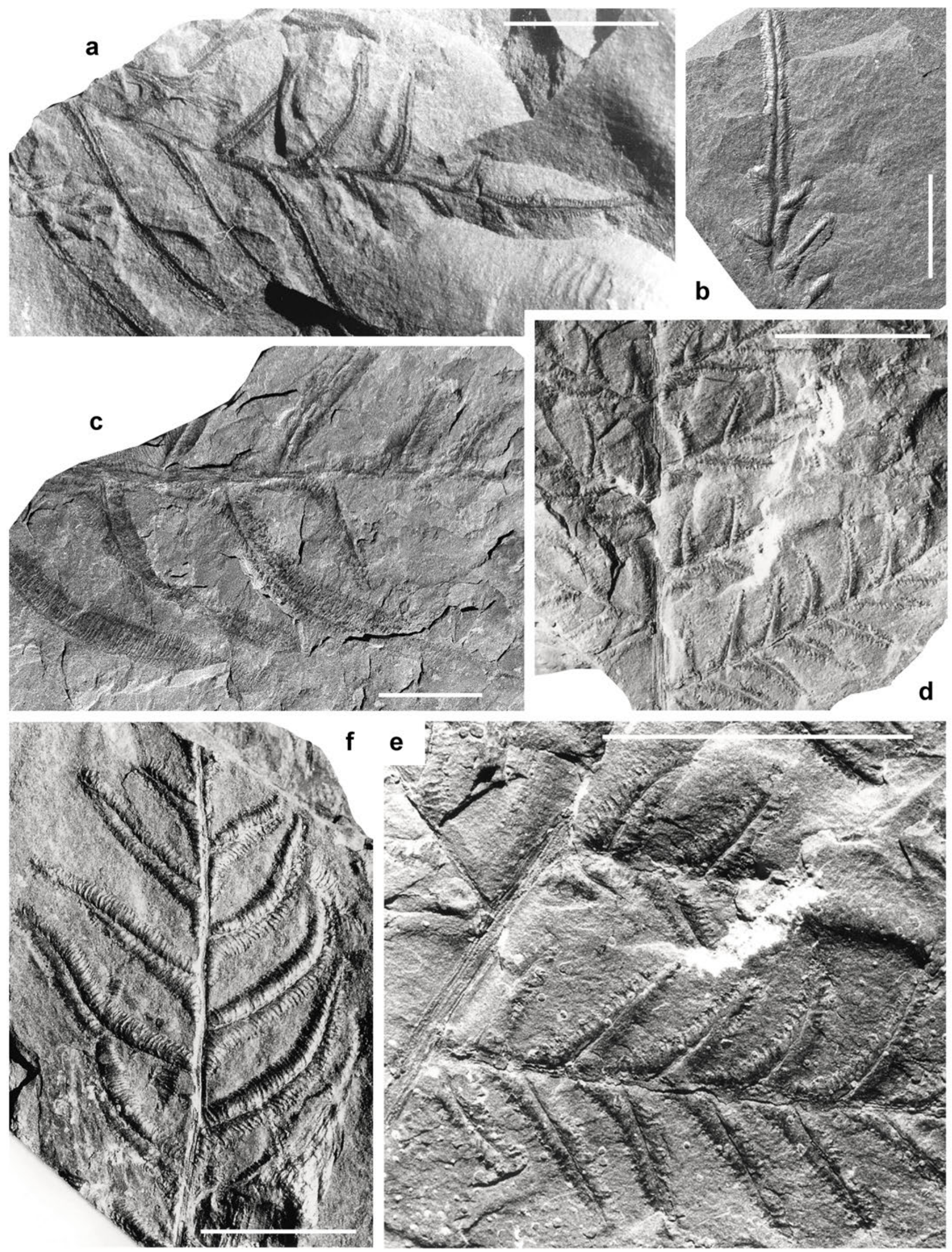
is consistent. Shorter pinnules straight, subtriangular, with bluntly pointed apex; longer pinnules narrow, parallel-sided and only tapering in the near-apical part, either arched or flexuous. Dimensions: 6-20 $\mathrm{mm}$ long and $2.5-3 \mathrm{~mm}$ wide; length/breadth ratio $=2.5-6.5$. Lamina thick, convex, with a compression border not always visible. Venation characterized by a midrib straight, slightly decurrent, well marked in the vaulted lamina and visible up to the apex. Lateral veins closely spaced, relatively thick, almost perpendicular to both the midrib and pinnule margins, single or once forked at variable distances from the midrib; veins are, on the whole, fairly regularly disposed. Vein density $=$ ca. $30-40$ veins per centimetre.

Remarks. Crookall (1955, text-fig. 8) reproduced Artis's original illustration of Alethopteris decurrens from Alverthorpe, Yorkshire, England (as reported by Cleal et al. 2009, most of Artis's specimens are lost). The holotype is a fragment of pinna of antepenultimate order with relatively strong rachises and widely spaced, confluent, oblique, narrow, almost parallel-sided ("linear") pinnules that tend to become elongate in the terminal part of pinnae. The most extensive documentation of Alethopteris decurrens was published by Buisine (1961), who figured material from northern France. Previously, Boulay (1876) had introduced a new species, Alethopteris gracillima, also from northern France, which appears identical to Alethopteris decurrens. Although some authors consider Alethopteris gracillima to be a variety of Alethopteris decurrens (e.g., Crookall 1955), I follow Zeiller (1888) and Buisine (1961) in considering Alethopteris gracillima a junior synonym of Alethopteris decurrens.

Bell $(1944,1966)$ illustrated several, very characteristic, specimens of Alethopteris decurrens from Nova Scotia showing the widely spaced, elongate and narrow pinnules with strongly marked, fairly regularly disposed lateral veins, most of which are once forked. Previously, Bell (1938) described a new species, Alethopteris scalariformis, from the Sydney coalfield, as closely resembling Alethopteris decurrens. Bell noted closer and non-decurrent pinnules (except near the apical parts) in Alethopteris scalariformis, and more widely spaced veins that are dichotomized at wider angles. I agree with Crookall (1955) that these superficial differences do not appear to be of specific value and thus consider Alethopteris scalariformis to be a taxonomic junior synonynm of Alethopteris decurrens.

Comparisons. Alethopteris decurrens is a distinctive species, identified without much difficulty. Only Alethopteris davreuxii could pose problems, but it possesses more rigid pinnules that are subtriangular and tend to become slightly more tapering. Most characteristic of Alethopteris davreuxii is its wide venation characterized by once to twice forked veins of flexuous, almost anastomosing aspect. Vein density in Alethopteris decurrens is also distinctive, with some 30-45 veins per centimetre according to Buisine (1961). Although Alethopteris urophylla shows generally larger and broader pinnules with a tendency to have a biconvex shape and, particularly, a well-marked constriction at the base on the acroscopic side, occasional specimens occur with narrower pinnules that resemble those of Alethopteris decurrens. But Alethopteris urophylla possesses higher vein density (48-55 veins per centimetre), and it rarely shows unforked lateral veins.

Stratigraphic and geographic distribution. Alethopteris decurrens is relatively widespread. The holotype is from lower Westphalian strata of the Yorkshire Coalfield, England. According to Crookall (1955), the species ranges in Great Britain from Westphalian A to C (Langsettian to Bolsovian), being most common in Westphalian B (Duckmantian) and sporadic in Westphalian C (Bolsovian). Šimůnek (1996) recorded it from Namurian C and Westphalian A (Langsettian) strata of the Upper Silesian Basin, and from the Namurian C to the Westphalian B (Duckmantian) of the Intrasudetic Basin. Both Alethopteris tectensis and Alethopteris edwardsii originated from the same (undetermined) locality in the Assisse d'Andenne, upper Namurian (Yeadonian) of Belgium - although Stockmans and Willière (1953) did not rule out the possibility that the specimens came from the Assise de Chokier. In Donbass, Alethopteris decurrens ranges

Figure 3. (previous page) (a) Alethopteris decurrens. Last order pinna showing the narrow, parallel-sided, flexuous, longer pinnules. Note the elongate, well-individualized apical pinnule. Origin: Chimney Corner area, Inverness County, Cape Breton Island, shore about $2 / 3$ mile north of the old coal mine (locality 1420). (b) Alethopteris decurrens. Specimen without catalogue number showing the characteristic, elongate and parallel-sided apical pinnule. Origin: Parrsboro shore between Moose River and Moose Creek (locality 1450). Repository: Geological Survey of Canada, Ottawa. (c) Alethopteris decurrens. NBMG 3403. Last order pinna with long, arched pinnules. Origin: Fern Ledges, Saint John, New Brunswick. Repository: New Brunswick Museum, Saint John. (d) Alethopteris decurrens. GSC 9313. Penultimate order pinna showing closely spaced last order pinnae with the subtriangular, shorter pinnules. Previously figured by Bell (1944, pl. XLII, fig. 5; pl. XLV, fig. 5). Origin: Chimney Corner area, Inverness County, Cape Breton Island, shore about $1.2 \mathrm{~km}$ north of the old coal mine (locality 1420). (e) Enlargement of part of specimen in Fig. 3d to show the straight, slightly decurrent midrib, well-marked in the vaulted lamina and visible up to the apex; also the thick, spaced lateral veins. (f) Alethopteris decurrens. GSC 9315. Fragment of last order pinna showing the thick, convex lamina and the well-marked venation, composed by a straight midrib and closely spaced lateral veins almost perpendicular to both the midrib and pinnule margins, single or once forked. Previously figured by Bell (1944, pl. XLV, fig. 6). Origin: Parrsboro shore between Moose River and Moose Creek (locality 1406). Repository: Geological Survey of Canada, Ottawa. Scale bar $=1 \mathrm{~cm}$. 


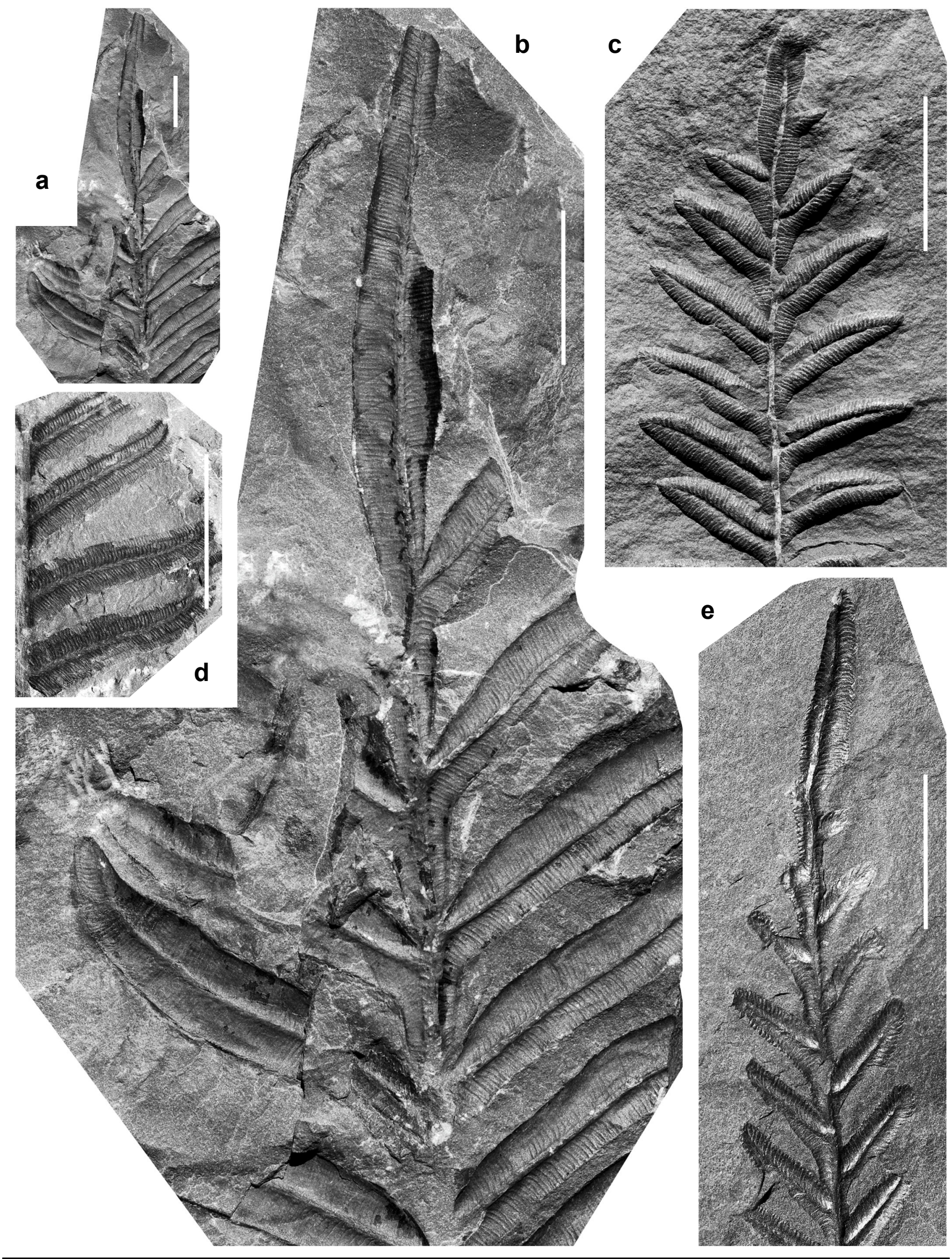


from middle Bashkirian $\left(\mathrm{C}_{2}{ }^{1}\right)$ to lower Moscovian $\left(\mathrm{C}_{2}{ }^{6}\right)$ (Namurian C to Bolsovian) (see Fissunenko in Solovieva et al. 1996).

Occurrence in the Maritime Provinces, Canada. CumberLAND BASIN (Nova Scotia): Bell (1944): locality 1070 (one piece without catalogue number - together with Cordaites sp.); locality 1338 (GSC 11000); locality 1420 (GSC $9313-$ here Figs. 3d-3e); locality 1435 (GSC 9315 + GSC 9320 + GSC 9323 + six pieces without catalogue number - together with Renaultia sp., Bergeria dilatata and Annularia ramosa); locality 1450 (three pieces without catalogue number); locality 1982 (fragmentary - one piece without catalogue number); locality 2982 (one piece without catalogue number). Bell (1966): locality 1450 (GSC 14995). DonALD REID COllection, Joggins, Nova SCOTIA (1999): DRC-997-55. SAINT John (New Brunswick): Bell (1944): locality 2573 (one piece without catalogue number). New Brunswick Museum: NBMG 3403 (labelled as the type of Alethopteris discrepans var. arctus, an unpublished name). SYDNEY BASIN (Nova Scotia): Bell (1938): locality 752 (GSC 2640 + GSC 2642 + GSC 2647 - holotype of Alethopteris scalariformis + GSC 2668).

Occurrence in the United States. Alabama: Gillespie and Rheams (1985). ILLINOIS: Janssen (1957), Read and Mamay (1964), Jennings (1984). Michigan: Arnold (1934), Arnold (1949). Missouri: Basson (1968). OHIO: Cross et al. (1996). West Virginia: Gillespie and Pfefferkorn (1976), Pfefferkorn and Gillespie (1977), Gillespie et al. (1978).

\section{Alethopteris cf. havlenae Šimůnek 1996}

(Figs. 5a-e)

1970 Alethopteris lonchitica f. serlii Brongniart; Havlena, p. 97, pl. II, fig. 5.

cf. 1977 Alethopteris lonchitica Schlotheim ex Sternberg; Leary and Pfefferkorn, p. 25-27, pl. 9, figs. 1-6 (specimens previously mentioned in Leary 1976, p. 4); text-figs. 9A-D (acc. to Wagner and Álvarez-Vázquez 2008).

* 1984 Alethopteris densinervosa Wagner; Havlena, p. 370-371, pl. I, figs. 2, 3 (designated by Šimůnek 1996 as the holotype of Alethopteris havlenae); pl. II, figs. 2, 3 (same as Alethopteris lonchitica f. serlii, Havlena 1970, pl. II, fig. 5).

T k 1996 Alethopteris havlenae Šimůnek, p. 10-11, pl. V, figs. 5, 7-8, fig. 6 (cuticle); pl. VI, fig. 1, figs. 2-3 (holotype), figs. $4-5,7$, figs. 6,8 (cuticles); textfigs. 11-13.

? 2014 Alethopteris urophylla (Brongniart) Göppert; Bashforth et al., p. 247, pl. III, figs. 3, 4, 6-7, 9 (fragmentary).

Description. Frond at least bipinnate. Last order pinna apparently subrectangular (always incomplete), with parallel margins. Last order rachis straight, ca. $0.5-1 \mathrm{~mm}$ wide. Pinnules inserted obliquely $\left(50-60^{\circ}\right)$, closely placed; asymmetrical, tongue-shaped, with convex margins, rounded apex, narrowly confluent on the basiscopic side and with a marked constriction on the acroscopic. Apical pinnule not preserved. Dimensions: $4-12 \mathrm{~mm}$ long and $2-5 \mathrm{~mm}$ broad; length/breadth ratio $=2-2.5$. Lamina relatively thick, vaulted. Venation composed by a midrib straight, relatively wide, extending to near the pinnule apex. Lateral veins thin, leaving the midrib almost at right angle and reaching the pinnule margin at $80-85^{\circ}$ on the basiscopic side and at $55-85^{\circ}$ on the acroscopic one; generally once forked near the midrib, rarely twice. Subsidiary veins once forked. Vein density $=55-60$ veins per centimetre.

Remarks. Alethopteris havlenae is characterized by closely spaced, tongue-shaped, asymmetrical pinnules with rounded apex and the narrowly confluent base on the basiscopic side. The species was introduced by Šimůnek (1996) to accommodate specimens from the Upper Silesian Basin previously determined as Alethopteris serlii by Šusta (1928) and Alethopteris densinervosa by Havlena (1984).

I include in Alethopteris havlenae two previously unfigured specimens stored in the New Brunswick Museum, Saint John, and another two from the collections of the Geological Survey of Canada, Ottawa; these specimens came from Fern Ledges. Also included as Alethopteris havlenae are five specimens figured as Alethopteris urophylla by Bashforth et al. (2014) from the Tynemouth Creek Formation, New Brunswick. All these specimens are fragmentary, which is why I include them questionably in Alethopteris havlenae.

Comparisons. Alethopteris serlii has pinnules of similar

Figure 4 (previous page). (a) Alethopteris urophylla. Apical part of a pinna. Specimen without catalogue number. Previously figured by Wagner and Álvarez-Vázquez (2008, figs 7a, 7b). Origin: Springhill, from unspecified coal mine (locality 205). (b) Enlargement of specimen in Fig. 4a. Note the well-individualized, elongate, apical pinnule, and the narrowly confluent bases, with a constriction on the acroscopic side, of lateral pinnules. Repository: Geological Survey of Canada, Ottawa. (c) Alethopteris urophylla. DRC-997-57. Sideritized specimen showing smaller pinnules, subtriangular, with bluntly pointed apex. Origin: Joggins section (Donald Reid Collection). Repository: Joggins Fossil Centre, Joggins, Nova Scotia. (d) Alethopteris decurrens. Specimen without catalogue number. Origin: Springhill, mine $\mathrm{n}^{\circ} 7$ (locality 1070). (e) Alethopteris decurrens. Specimen without catalogue number. Terminal part of last order pinna showing the well-individualized, elongate, parallel-sided, and with a sharply pointed apex apical pinnule. Counterpart of Bell (1966, pl. IV, fig. 4). Origin: Parrsboro shore between Moose River and Moose Creek (locality 1450). Repository: Geological Survey of Canada, Ottawa. Scale bar $=1 \mathrm{~cm}$. 

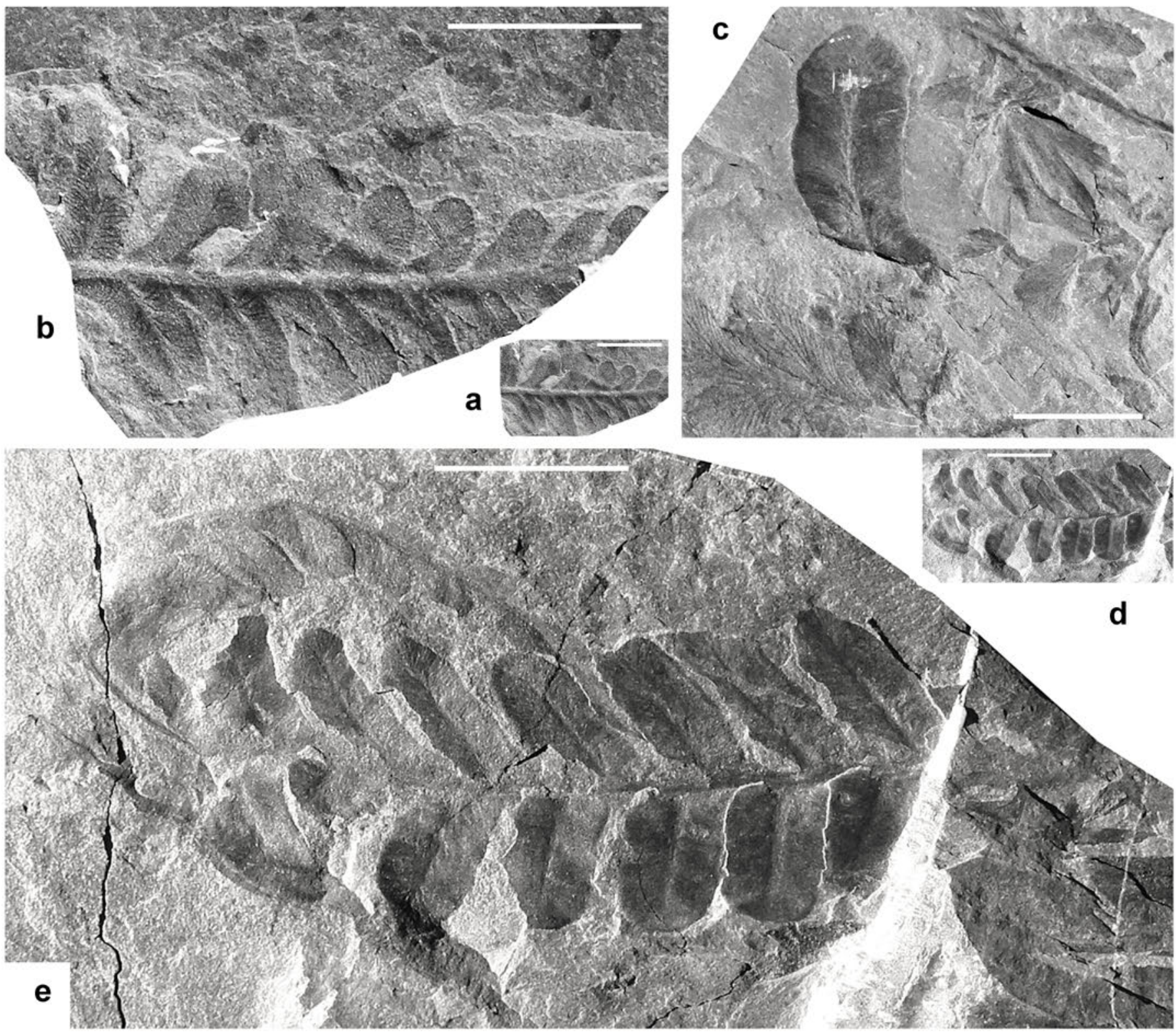

Figure 5. (a) Alethopteris cf. havlenae. NBMG 7559. Origin: Duck Cove, Saint John, Lancaster, New Brunswick. (b) Enlargement of Fig. 5a to show the obliquely inserted pinnules and thin lateral veins. Repository: New Brunswick Museum, Saint John. (c) Alethopteris cf. havlenae. Specimen without catalogue number. Isolate pinnule. Origin: Fern Ledges, Saint John, New Brunswick (locality 2254). Repository: Geological Survey of Canada, Ottawa. (d) Alethopteris cf. havlenae. NBMG 7495. Origin: Duck Cove, Saint John, Lancaster, New Brunswick. Repository: New Brunswick Museum, Saint John. Scale bar $=1 \mathrm{~cm}$. (e) Enlargement of Fig. 5d to show the tongue-shaped pinnules, with convex margins and rounded apex that are narrowly confluent on the basiscopic side and with a marked constriction on the acroscopic.

shape, but with more convex margins and a bluntly acuminated apex; vein density is also different, $30-35$ veins per centimetre in Alethopteris serlii compared with 55-60 in Alethopteris havlenae. Alethopteris densinervosa shows clearly biconvex and more closely spaced pinnules that have a slightly higher ratio (2.5-3 times longer than broad); in addition, the midrib is not as thick as in Alethopteris havlenae, and lateral veins are fine and less numerous, about 40-45 veins per centimetre according to Wagner (1968). Alethopteris valida is characterized by its thick lamina and large, subtriangular pinnules connected by a broadly confluent lamina, about 2-3 mm wide; moreover, vein density is lower, about $25-30$ veins per centimetre in the pinnule margin.

Stratigraphic and geographic distribution. Alethopteris havlenae is rarely reported. The holotype is from Namurian C strata of the Karviná Formation in the Upper Silesian Basin. Šimůnek (1996) reported the species in the Namurian C and the Westphalian A (Langsettian) of this basin. 
Occurrence in the Maritime Provinces, Canada. SAINT JoHn (New BRUnswick): Bell (1944): locality 2214 (one piece without catalogue number - together with Rhacopteris sp.); locality 2254 (one piece without catalogue number - together with Neuropteris obliqua). New BRUNSwick Museum: NBMG 1740 + NBMG 7559. Bashforth et al. (2014): NBMG 15440 + NBMG 15441 + NBMG 16210 + NBMG 16729 + NBMG 16730.

Occurrence in the United States. IllinoIs: Leary (1976); Leary and Pfefferkorn (1977).

\section{Alethopteris urophylla (Brongniart 1834) Göppert 1836}

(Figs. 1c, 4a-c, 6)

${ }^{*} \mathrm{v} 1834$ Pecopteris urophylla Brongniart, p. 290-291, pl. 86.

$\$ 1836$ Alethopteris urophylla (Brongniart) Göppert, p. 300.

* 1848 Pecopteris multiformis Sauveur, pl. XXXVI, fig. 1 (acc. to Wagner and Álvarez-Vázquez 2008).

* 1862 Pecopteris (Alethopteris) decurrens sp. nov. Dawson (non Artis), p. 322, pl. XV, figs. $40 \mathrm{a}-\mathrm{c}$ (diagrammatic drawings of fragmentary specimens).

* 1862 Pecopteris (Alethopteris) ingens sp. nov. Dawson, p. 322, pl. XV, figs. 41a-b (see comments in Stopes 1914, p. 95-96).

* 1863 Pecopteris discrepans Dawson, p. 468 (name change on the basis of the homonymy of Dawson's 1862 Pecopteris (Alethopteris) decurrens with Lesquereux's 1858 Pecopteris decurrens. However, the real homonym is Artis's Filicites decurrens $=$ Alethopteris decurrens).

1865 Alethopteris discrepans Dawson, p. 136-137.

1868 Alethopteris discrepans Dawson, p. 552-553, fig. 192I (same of Dawson 1862, pl. XV, fig. 40a).

p ? $1871 \quad$ Alethopteris discrepans Dawson, pl. XVIII, fig. 205 (this schematic figure cannot be properly judged; it can be also compared with Alethopteris decurrens); non p. 54, pl. XVIII, fig. 203 (= Alethopteris bertrandii); non pl. XVIII, figs. 204-204c (= Alethopteris bertrandii).

p 1910 Johannophyton discrepans (Dawson) Matthew, pl. III, fig. 3; pl. III, figs. 7, 9; non pl. II, fig. 7 (= Alethopteris bertrandii); non pl. III, fig. 1 (= Alethopteris bertrandii - same as Dawson 1871, pl. XVIII, fig. 203); non pl. II, figs. 8-9 (sporangia); non pl. III, figs. 2, 4-6 (same as Dawson 1871, pl. XVIII, figs. 204-204c); non pl. III, figs. 8, 10 (sporangia).

v p 1914 Alethopteris lonchitica (= Alethopteris discrepans) Schlotheim ex Sternberg; Stopes, pl. XII, fig. 30; text-figs. 8A-C (diagram- matic drawings); non p. 47-53, pl. XIII, fig. 31 (photographic illustration of Dawson 1871, pl. XVIII, fig. 204 - here Alethopteris bertrandii); non pl. XIII, fig. 32 (fragmentary and poorly illustrated - compared with Alethopteris corsinii by Wagner and Álvarez-Vázquez 2008 and here included in Alethopteris bertrandii); non pl. XIII, fig. 33 (comparable with Alethopteris decurrens); non pl. XVIII, fig. 46 (sporangia and pinnule fragments that, acc. to Wagner and Álvarez-Vázquez 2008, may belong either to Alethopteris sp. or Neuralethopteris sp.); non pl. XXII, fig. 57A (= Alethopteris sp. indet. acc. to Wagner and Álvarez-Vázquez 2008). Alethopteris lonchitica Schlotheim ex Sternberg; Corsin, p. 18, pl. VIII, figs. 1-1a; textfig. 7.

1935 Alethopteris grandifolia Newberry; Arnold, p. 280, fig. 1 (last order pinna with associated seed), fig. 3 (last order pinna with attached seed).

1937 Alethopteris grandifolia Newberry; Arnold, p. 46, fig. 1 (drawing of the fragment of last order pinna figured in Arnold 1935, fig. 3).

1944 Alethopteris lonchitica Schlotheim ex Sternberg; Bell, p. 86-87.

1949 Alethopteris Helenae Lesquereux; Arnold, p. 188-189, pl. XIX, figs. 5-6.

p 1961 Alethopteris lonchitica Schlotheim ex Sternberg; Buisine, p. 99-115, pl. XIII, fig. 1; pl. XIII, figs. 2-2b; pls. XIV-XVI; pl. XVII, fig. 2, 4; pl. XVIII, figs. 1-1b; pls. XIX, XX; text-figs. 9a-c; non pl. XVII, figs. 1, 3 (= Alethopteris densinervosa acc. to Wagner and Álvarez-Vázquez 2008); non pl. XVIII, fig. 2 (= Alethopteris densinervosa acc. to Wagner and Álvarez-Vázquez 2008).

p 1961 Alethopteris serli (Brongniart) Göppert; Buisine, pl. VIII, figs. 2-2a (= Alethopteris urophylla acc. to Wagner 1968); non pls. IVII, non pl. VIII, figs. 1-1a (= Alethopteris densinervosa acc. to Wagner 1968); non pl. IX, figs. 1-1a (= Alethopteris westphalensis acc. to Wagner, 1968); non pl. X, figs. 1-1a, 3-4 (= Alethopteris densinervosa acc. to Wagner 1968); non pl. IX, figs. 1-1a, pl. X, figs. 2-2a, pl. XI, figs. 1-2, pl. XII, figs. 1a-1c (= Alethopteris westphalensis acc. to Wagner 1968).

1963 Alethopteris decurrens (Artis) Frech; Wood, p. $48-49$, pl. 5, fig. 9.

v 1966 Alethopteris lonchitica Schlotheim ex Sternberg; Bell, p. 16, pl. VII, fig. 4.

p 1985 Alethopteris lonchitica Schlotheim ex Sternberg; Gillespie and Rheams, p. 194, 199, pl. II, fig. 2; non pl. I, fig. 3 (Alethopteris valida 


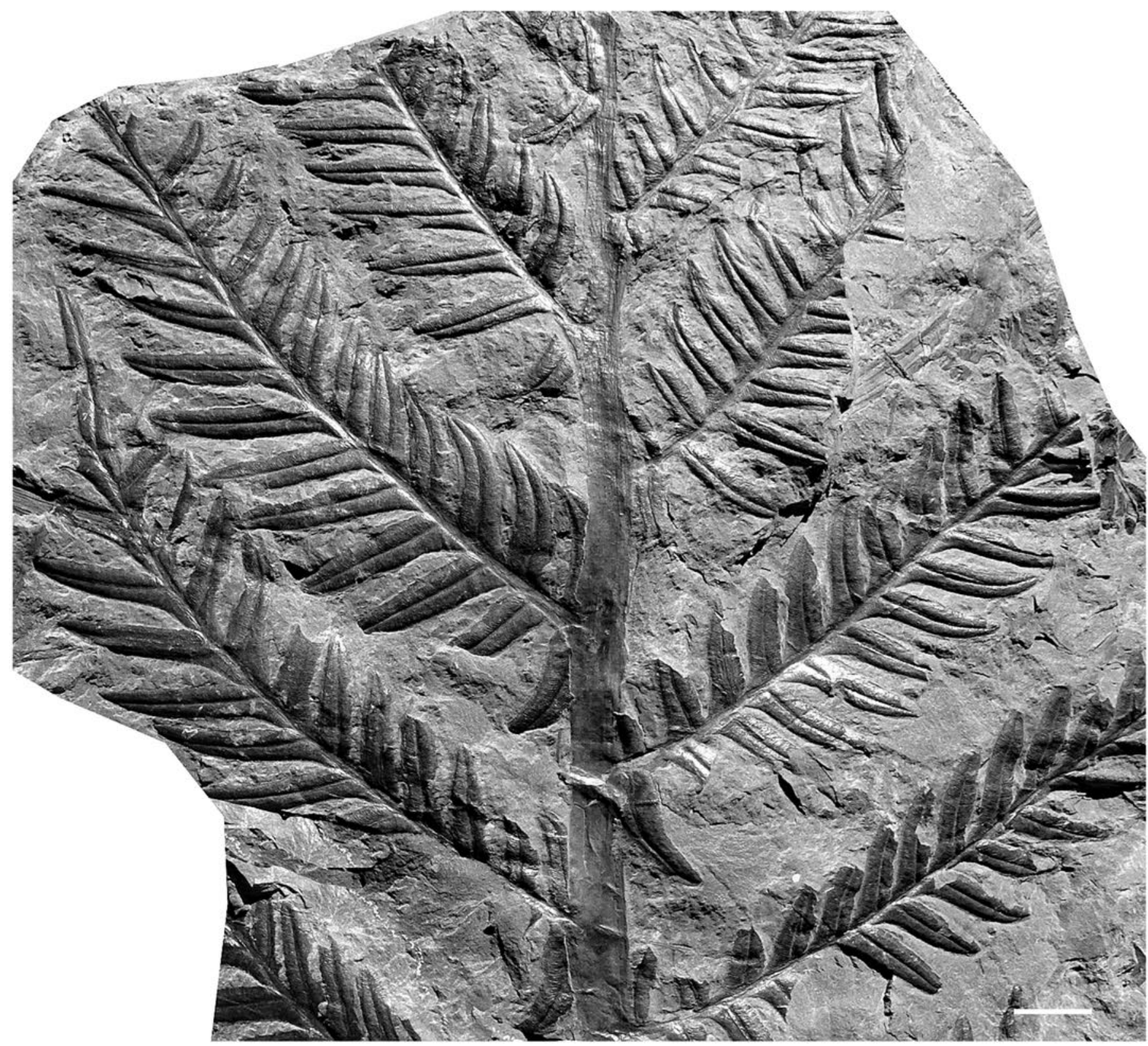

Figure 6. Alethopteris urophylla. GSC 14994. Large specimen showing the sturdy, narrowly confluent, asymmetrical pinnules that characterize Alethopteris urophylla. Previously figured by Bell (1966, pl. VII, fig. 4). Origin: Springhill mines (locality 205). Repository: Geological Survey of Canada, Ottawa. Scale bar $=1 \mathrm{~cm}$.

acc. to Wagner and Álvarez-Vázquez 2008). Alethopteris lonchitica Schlotheim ex Sternberg; Gillespie et al., p. 5, pl. 2, fig. 7.

p 1996 Alethopteris urophylla (Brongniart) Göppert; Šimůnek, p. 13-16, pl. X, figs. 1, 4 (after Šusta 1928, Taf. XXXIV, fig. 3), fig. 6 (trichome); pl. XI, fig. 1 (after Purkyňová 1990, Tab. II, fig. 4), figs. 2-7 (cuticles); pl. XII, fig. 1 (fragmentary; difficult to judge), figs. 2-4, fig. 5 (?), figs. 6-10 (cuticles); pl. XIII, figs. 1-8 (cuticles); pl. XIV, fig. 1; text-figs. 18-23; non pl. X, figs. 2-3 (resemble Alethopteris decurrens); non pl. X, fig. 5 (difficult to judge, but resembles Alethopteris havlenae); non text-fig. 17 (possibly Alethopteris havlenae). 1997 Alethopteris lonchitica Schlotheim ex Sternberg; Blake, p. 84, 85, pl. 2, figs. 1-3.

2002 Alethopteris decurrens (Artis) Frech; Blake et al., p. 264, 268, 291, pl. XVIII, fig. 2.

? 2002 Alethopteris urophylla (Brongniart) Göppert; Blake et al., p. 264, 269, 291, 292, pl. XVIII, figs. $3,5$.

? 2006 Alethopteris discrepans (cf. A. lonchitica) Dawson; Calder et al., fig. 11B (difficult to 
judge from the illustration at less than natural size).

2006 Alethopteris Sternberg; Falcon-Lang, p. 44, fig. 10C (only an isolated pinnule but showing the slightly biconvex margins, bluntly acuminated apex and the constriction on the acroscopic side characteristic of the species).

v T 2008 Alethopteris urophylla (Brongniart) Göppert; Wagner and Álvarez-Vázquez, p. 166-177 (including synonymy), fig. 1 (copy of Brongniart 1834, pl. 86), figs. 2-4 (photograph of the holotype), figs. 5-7d, figs. 8a-10 (same specimen as in Buisine 1961, pl. XIII, fig. 1), figs. 11a-12.

v 2010 Alethopteris urophylla (Brongniart) Göppert; Wagner and Álvarez-Vázquez, p. 257, 258, 261 262, 266, 307, pl. IX, fig. 1 (together with Paripteris gigantea - same as Wagner and Álvarez-Vázquez 2008, fig. 11a).

Excludenda (including Alethopteris lonchitica autorum): 1879-80 Alethopteris lonchitica Schlotheim ex Sternberg; Lesquereux, p. 177-179, pl. XXVIII, figs. 7-7a (= Alethopteris lancifolia acc. to Wagner and Álvarez-Vázquez 2008).

1938 Alethopteris lonchitica Schlotheim ex Sternberg; Bell, p. 67, pl. LXI, fig. 5 (refigured by Zodrow and Cleal 1998, pl. 2, fig. 3 - acc. to Wagner and Álvarez-Vázquez 2008, it may be attributed to the Alethopteris lonchitifoliawestphalensis complex).

1939 Alethopteris lonchitica Schlotheim ex Sternberg; Janssen, p. 143, fig. 129 (mentioned in Leary 1976) (difficult to judge from the illustration; Wagner and Álvarez-Vázquez 2008 compared with Alethopteris lonchitifolia).

1958 Alethopteris lonchitica Schlotheim ex Sternberg; Langford, p. 241, figs. 438-439 (mentioned in Leary 1976) (Wagner and Álvarez-Vázquez 2008 compared with Alethopteris lesquereuxii).

1962 Alethopteris lonchitica Schlotheim ex Sternberg; Bell, pl. XLII, fig 4. (= Alethopteris cf. davreuxii? acc. to Wagner and ÁlvarezVázquez 2008).

1977 Alethopteris lonchitica Schlotheim ex Sternberg; Leary and Pfefferkorn, p. 25-27, pl. 9, figs. 1-6 (previously mentioned in Leary 1976, p. 4); text-fig. 9A-D (comparable with Alethopteris havlenae acc. Wagner and Álvarez-Vázquez 2008).

1978 Alethopteris lonchitica Schlotheim ex Sternberg; Gillespie et al., p. 100, pl. 35, fig. 3 (venation diagram); pl. 36, fig. 7 (acc. to Wagner and Âlvarez-Vázquez 2008, pointed pinnules tending to a lanceolate shape not suggestive of Alethopteris urophylla).

1982 Alethopteris lonchitica Schlotheim ex Stern- berg; Olekyshyn, p. 98-99, figs. 19F-H (acc. to Wagner and Álvarez-Vázquez 2008 resembles Alethopteris missouriensis).

1985 Alethopteris cf. lonchitica Schlotheim ex Sternberg; Lyons et al., pl. XI, fig. b (fragmentary and difficult to judge - either Neuralethopteris sp. indet. or Alethopteris sp. indet. acc. to Wagner and Álvarez-Vázquez 2008).

2014 Alethopteris lonchitica Schlotheim ex Sternberg; Moore et al., p. 38, 39, pl. VII, figs. 7-8 (fragmentary; comparable with Alethopteris lesquereuxii).

2014 Alethopteris urophylla (Brongniart) Göppert; Bashforth et al., p. 247, pl. III, figs. 3, 4, 6-7, 9 (although fragmentary, comparable with Alethopteris havlenae).

Description. Frond at least tripinnate. Penultimate order rachis strong, flat, straight, longitudinally striate, up to $10 \mathrm{~mm}$ wide. Last order pinnae alternate, close or slightly touching laterally; subrectangular, parallel-sided, tapering only in the distal part; lateral pinnules in the terminals only slightly shorter than the other laterals; apical pinnule well-individualized, elongate, parallel-sided, with a sharply pointed apex, up to $35 \mathrm{~mm}$ long. Dimensions: up to $130 \mathrm{~mm}$ long (incomplete) and $20-60 \mathrm{~mm}$ broad. Last order rachis inserted at $45-80^{\circ}$, straight, longitudinally striate, ca. $0.5-1.5 \mathrm{~mm}$ wide. Lateral pinnules spaced (3-5 mm), oblique to the rachis (at $45-80^{\circ}$ ), decurrent, with narrowly confluent bases and a constriction on the acroscopic side. Pinnule length variable depending on the position in the frond, whilst retaining the approximate width. Shorter pinnules straight, subtriangular, with bluntly pointed apex; longer pinnules parallel-sided to slightly biconvex, tapering in the near-apical part to a bluntly acuminate to rounded apex, either arched or flexuous. Dimensions: 9-27 $\mathrm{mm}$ long and $2.5-5 \mathrm{~mm}$ wide; length/ breadth ratio $=3.6-5.4$. Lamina thick, convex, with a compression border not always clearly visible. Venation well marked, characterized by a midrib straight, very slightly decurrent, deeply imprinted in the lamina and extending up to near pinnule apex. Lateral veins thin, regularly disposed and closely spaced, slightly curved near the midrib and reaching the pinnule margin at right angles; generally once forked at variable distances from the midrib, rarely simple or with a second bifurcation. Subsidiary veins simple or once forked. Vein density $=48-55$ veins per centimetre.

Remarks. Alethopteris urophylla was discussed by Wagner and Álvarez-Vázquez (2008), who refigured and described the holotype (Brongniart 1834, pl. 86) and provided a full synonymy list. Comments on the synonymy are repeated herein if relevant to the Canadian and American material.

Originally described from Merthyr Tydfil in South Wales (Brongniart 1834), Alethopteris urophylla has been recorded widely from the Pennsylvanian paleoequatorial belt as represented in North America and Europe. Records have been mostly under the name of Alethopteris lonchitica, a 
Stephanian species that Zodrow and Cleal (1998) showed to be different from Alethopteris urophylla (see also Wagner and Álvarez-Vázquez 2008).

Buisine (1961) discussed Alethopteris discrepans, a substitute name provided by Dawson (1863) for Pecopteris (Alethopteris) decurrens, which was introduced by Dawson (1862) (see comment in the synonymy list); this species is based on diagrammatic drawings of very fragmentary specimens. In agreement with Stopes (1914), Buisine, included Alethopteris discrepans as a taxonomic junior synonym of Alethopteris lonchitica (meaning Alethopteris lonchitica auctorum $=$ Alethopteris urophylla). This synonymy is supported by the illustration of material from Dawson's original locality, the Fern Ledges at Saint John, New Brunswick, as well as other fragmentary remains from the Joggins section, Nova Scotia (see Stopes 1914).

Although Bell (1944, p. 87) mentioned Alethopteris lonchitica as the most abundant and widespread species in the Cumberland Group (he recorded it from 57 localities), he gave only a short description and no illustrations. Only at a later date did he figure a large and well-preserved specimen from Springhill (Bell 1966, pl. VII, fig. 4 - herein Fig. 6). The present restudy of the collections of the Geological Survey of Canada and the Joggins Fossil Institute confirms the abundance of Alethopteris urophylla in the Maritime Provinces.

Comparisons. Alethopteris lonchitica also shows parallelsided pinnules of similar size, but they are slender and have a more broadly rounded apex. In addition, pinnules in Alethopteris lonchitica tend to be more pecopteroid and perpendicular to the rachis, and the midrib is wider and lateral veins more widely spaced. Alethopteris decurrens has narrower and more-parallel-sided pinnules that are much more spaced out; additionally, longer pinnules are arched or flexuous, vein density is lower, ca. $30-40$ veins per centimetre, and lateral veins seem to be more irregular. Althopteris corsinii has pinnules of similar shape and size, but they are broader and more broadly confluent, with less marked constriction on the acroscopic side; venation is wider, only $30-35$ veins per centimetre on the pinnule margin, and lateral veins are simple or fork once close to the midrib. Alethopteris bertrandii possesses larger, stiff, lanceolate pinnules. In addition, venation is wider, with about $40-45$ veins per centimetre on the pinnule margin (Buisine 1961), and the elongate last order pinna terminals are very characteristic. Alethopteris solutifolia also possess decurrent, parallel-sided pinnules with rounded apex, narrowly confluent bases and a constriction on the acroscopic side; but the pinnules in that species are longer and narrower. Additionally, lateral veins are forked up to three times and are more widely spaced, with about 35 veins per centimetre in the pinnule margin.

Stratigraphic and geographic distribution. Alethopteris urophylla is widespread in the paleoequatorial belt, from Michigan in the west to the Donbass in the east. The holotype is from from lower Westphalian horizons at Merthyr
Tydfil in South Wales. According to Wagner and ÁlvarezVázquez (2008), the species ranges from middle Namurian (Kinderscoutian) to lower Bolsovian, with most records from Langsettian and Duckmantian strata. Pecopteris multiformis was described originally from an unknown horizon in the lower Westphalian of Belgium.

Occurrence in the Maritime Provinces, Canada. Cumber-LANd Basin (Nova Scotia): Bell (1944): locality 999 (GSC 7562 - together with Calamites carinatus + GSC 8586 - together with Diaphorodendron decurtatum + GSC 9556 + GSC 9575 + eight pieces without catalogue number together with Zeilleria avoldensis); locality 1031 (GSC $10084+$ five pieces without catalogue number - with Cordaites sp. and seeds); locality 1052 (GSC 9879 - fragmentary but characteristic; together with Sphenophyllum cuneifolium, Cordaites sp. and Trigonocarpus sp.); locality 1070 (GSC 10192); locality 1081 (one piece without catalogue number); locality 1085 (two pieces without catalogue numbertogether with cf. Zeilleria hymenophylloides); locality 1089 (GSC 10164 + one piece without catalogue numberfragmentary); locality 1339 (one piece without cata-logue number); locality 1363 (one piece without catalogue number - fragmentary); locality 1491 (one piece without catalogue number - fragmentary and poorly preserved; with cf.); locality 1495 (one piece without catalogue number from a borehole - fragmentary and poorly preserved); locality 1498 (two pieces without catalogue number from a borehole fragmentary); locality 2986 (three pieces without catalogue number); locality 2991 (one piece without catalogue number - poorly preserved). Bell (1966): locality 205 (GSC 14994 - Fig. 6 herein + six pieces without catalogue number, three of them figured in Wagner and ÁlvarezVázquez 2008, figs. 7a-d - together with Calamites cistii and Sphenophyllum cuneifolium). Donald ReID COLleCtion, Joggins, Nova Scotia (1999): DRC-149-99 + DRC-15399 - together with Sigillaria scutellata and Lepidostrobophyllum lanceolatum. Fern Ledges, New BRUnswick: Stopes (1914): McGill University COllection 3312. New Brunswick Museum: NBMG 1805 (figured by FalconLang 2006) + NBMG 12056. Prince Edward Island: locality 4454 (two pieces without catalogue number).

Occurrence in the United States. Alabama: Gillespie and Rheams (1985). GEorgia: Gillespie et al. (1989). Indiana: Wood (1963). Michigan: Arnold (1949). Ohio: Arnold $(1935,1937)$. West Virginia: Blake et al. (2002).

Alethopteris cf. valida Boulay 1876

(Fig. 7)

* $1876 \quad$ Alethopteris valida Boulay, p. 35, pl. I, fig. 8.

* $1884 \quad$ Alethopteris Evansii Lesquereux, p. 834-835 (name and description only - acc. to Blake 1997, p. 82).

1886-88 Alethopteris valida Boulay; Zeiller, p. 231233, pl. XXXIII, figs. 1-2A; pl. XXXIV, figs. 1-1A. 


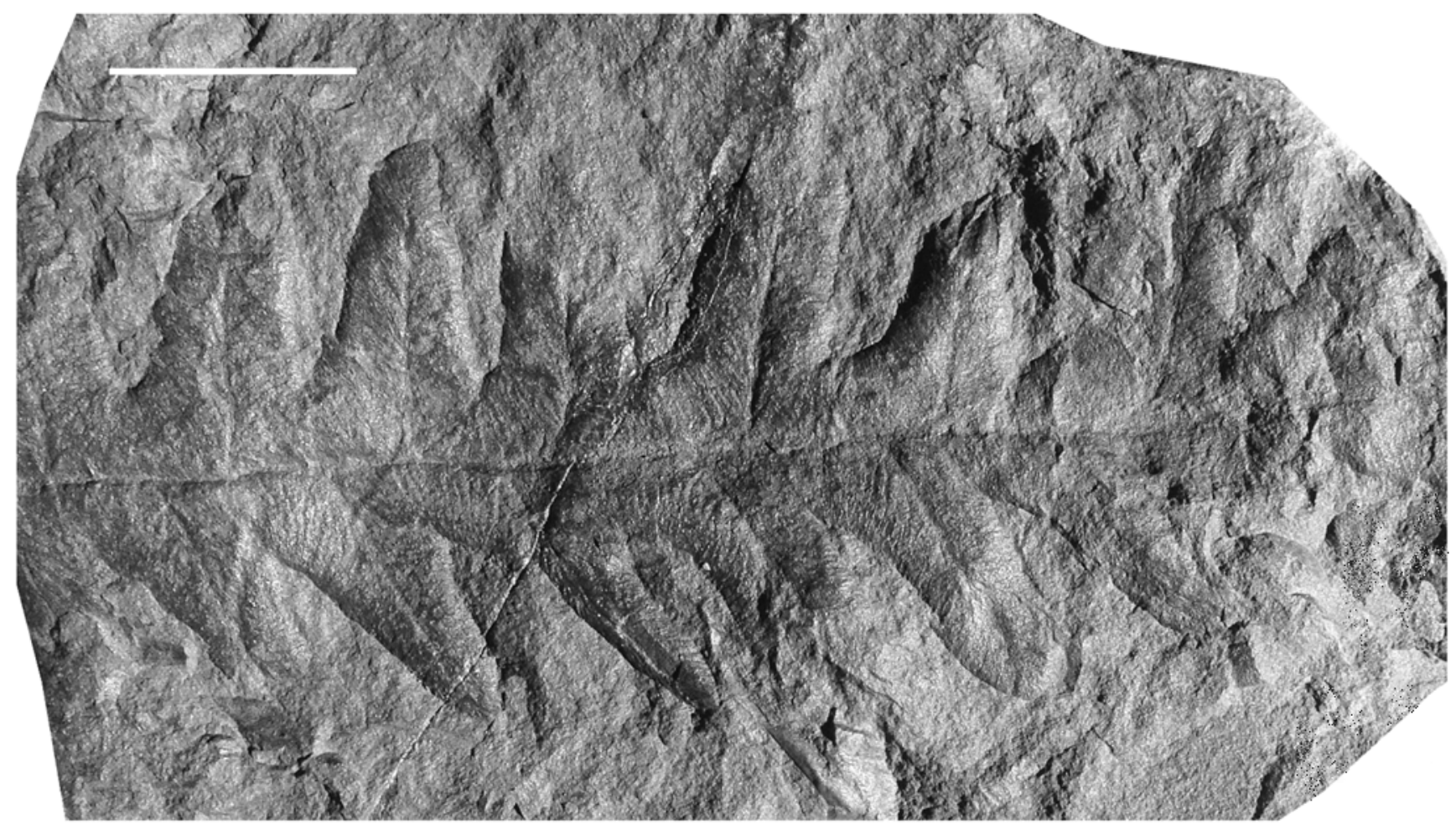

Figure 7. Alethopteris cf. valida. GSC 10852. Note the characteristic subtriangular pinnules and the broadly confluent lamina. Origin: Black river; Springhill area (locality 1178). Repository: Geological Survey of Canada, Ottawa. Scale bar $=1 \mathrm{~cm}$.

1900 Alethopteris Evansii Lesquereux; White, p. 887, pl. CXCII, figs. 7-8a.

1932 Alethopteris valida Boulay; Corsin, p. 19-20, pl. XI, figs. 1-1a; text-fig. 8 (same as Zeiller 1886, pl. XXXIII, figs. 1A-2A).

1951 Alethopteris nov. sp.?; Stockmans and Willière, pl. D, figs. 3-3a.

T 1955 Alethopteris valida Boulay; Crookall, p. 13-17, pl. I, figs. 3-4, figs. 5-5a (same as Crookall 1932, pl. VI, fig. 3); text-figs. 5A-B (drawings); text-fig. 5C (reproduction of Boulay's illustration).

? $1957 \quad$ Alethopteris davreuxi (Brongniart) Göppert; Janssen, p. 145, fig. 132 (difficult to judge from the illustration).

1959 Alethopteris (Callipteridium) sullivanti (Lesquereux) Fontaine and White; Canright, pl. 4, fig. 11.

T 1961 Alethopteris valida Boulay; Buisine, p. 168179 (including synonymy), pl. XLV, figs. $1-1 b$ (reillustration of the holotype), figs. 2-2a; pl. XLVI, fig. 1; pl. XLVII, figs. 1a-2b; pl. XLVIII, figs. 1-1b (same as Corsin 1932, pl. XI, fig. 1), fig. 2; text-figs. 15a-c.

1963 Alethopteris grandini Brongniart; Wood, p. 49 , pl. 6 , fig. 3 .

1963 Callipteridium sullivanti (Lesquereux) Weiss; Wood, p. 50, pl. 6, fig. 6. al., pl. 36, fig. 5; non pl. 36, fig. 3 (= Alethopteris davreuxii).

p 1985 Alethopteris lonchitica Schlotheim ex Sternberg; Gillespie and Rheams, p. 196, pl. I, fig. 3; non p. 194, 199, pl. II, fig. 2 (= Alethopteris urophylla).

1985 Alethopteris serli forma lonchitifolia Bertrand; Lyons et al., p. 228, 238, pl. XIII, figs. c-d.

? 1985 Alethopteris cf. integra (Gothan) Kidston; Gillespie and Crawford, p. 255, pl. III, fig. 4 (fragmentary).

k $1996 \quad$ Alethopteris valida Boulay; Šimůnek, p. 1820, pl. XV, figs. 7-8; pl. XVI, figs. 1-6; pl. XVII, figs. $1-3$, figs. $4-7$ (cuticles); pl. XVIII, fig. 1, figs. 2-8 (cuticles); text-figs 27-31.

1997 Alethopteris valida Boulay; Blake, p. 82, pl. 2, figs. 4-5.

1997 Alethopteris davreuxii (Brongniart) Göppert; Blake, p. 82, pl. 7, fig. 4; pl. 11, fig. 5.

2002 Alethopteris valida Boulay; Blake et al., p. 268, 290, pl. XVI, fig. 3.

2005 Alethopteris valida Boulay; Dilcher et al., p. 161, fig. 4.3.

2005 Alethopteris valida Boulay; Dilcher and Lott, pl. 131, fig. 1 (same as Dilcher et al. 2005, fig. 4.3), figs. 2-3.

Excludenda:

1938 Alethopteris valida Boulay; Bell, p. 68-69, 
pl. LXIV; pl. LXV, figs. 1-3; pl. LXVII, fig. 1 (Zodrow and Cleal 1998, p. 103 included all these specimens in Praecallipteridium cf. jongmansii).

1968 Alethopteris valida Boulay; Basson, pp. 7273, pl. 11, fig. 2 (comparable with Alethopteris grandinii).

1982 Alethopteris valida Boulay; Oleksyshyn, pp. 104-105, figs $20 \mathrm{G}-\mathrm{H}$ (the fragmentary specimens resemble Alethopteris lesquereuxii).

Description. Frond at least bipinnate. Last order rachis relatively straight, longitudinally striate, ca. $0.5 \mathrm{~mm}$. Pinnules spaced, slightly obliquely inserted, decurrent, with a broadly confluent lamina $(3 \mathrm{~mm})$; these are subtriangular, with a bluntly pointed apex. Dimensions: $10-12 \mathrm{~mm}$ long and $5 \mathrm{~mm}$ broad; length/breadth ratio $=2-2.4$. Lamina thick, vaulted. Midrib thin, clearly marked, visible in two third or more of the pinnule; lateral veins well spaced, one to twice forked, reaching the pinnule margin with a oblique angle. Vein density $=$ ca. 30 veins per centimetre.

Remarks. Alethopteris valida is a very distinctive species that has been regularly recorded from upper Namurian to middle Westphalian strata, although generally as fragmentary specimens and single records. The species was originally described by Boulay (1876) from northern France, from where it was documented extensively by Buisine (1961). Although specimens of this species have been figured from several basins in the United States, Bell $(1944,1966)$ did not record Alethopteris valida from the Maritmes. Figured and described here is a fragment of last order pinna; although fragmentary and not well preserved, it is sufficiently characteristic to be assigned tentatively to the species as Alethopteris cf. valida.

Comparisons. Alethopteris valida is a distinctive species, easily separated from members of the genus by its thick lamina and large, subtriangular pinnules united by a broadly confluent lamina. It resembles Lonchopteridium eschweilerianum, but the subreticulate venation of the latter are distinctive.

Stratigraphic and geographic distribution. Alethopteris valida ranges from (Marsdenian?) Yeadonian to lower Bolsovian. In the Nord de la France, Buisine (1961) recorded it from upper Namurian (Yeadonian) to upper Westphalian B (Duckmantian), being most abundant in Westphalian A (Langsettian) strata. In Great Britain it is mostly confined to Westphalian A and B (Langsettian and Duckmantian; see Crookall 1955). In the Intrasudetic Basin, Šimůnek (1996) recorded this species from Namurian C to Westphalian B.

Occurrence in the Maritime Provinces, Canada. Cumber-LAND Basin (Nova Scotia): locality 1178 (GSC 10852).

Occurrence in the United States. Alabama: Gillespie and
Rheams (1985), Lyons et al. (1985), Dilcher and Lott (2005), Dilcher et al. (2005). Georgia: Lesquereux (1884), Gillespie and Crawford (1985). IllinoIs: Janssen (1957). IndianA: Canright (1959); Wood (1963). Tennnessee: Lesquereux (1884). West Virginia: Gillespie et al. (1978), Blake (1997), Blake et al. (2002).

\section{Genus Neuralethopteris Cremer 1893 emend. Laveine 1967}

1893 Neuralethopteris Cremer, p. 32-33.

1965 Neuralethopteris Cremer; Wagner, p. 38, 39, 40.

1967 Neuralethopteris Cremer; Laveine, p. 97-102.

1995 Neuralethopteris Cremer; Cleal and Shute, p. 10, 12.

2000 Neuralethopteris Cremer; Goubet et al., p. 14-15.

2010 Neuralethopteris Cremer; Tenchov and Cleal, p. 300-301.

Type. Neuralethopteris schlehanii (Stur 1877) Cremer 1893.

Diagnosis. Pinnules tongue-shaped, with a cordate base, occasionally stalked in the proximal part, and more or less attached by the entire base in the distal part of the pinnae; apex more or less rounded. Terminal pinnule strongly varying in shape and size depending on the species: ovate, lanceolate or linear. Venation of alethopteroid type with a midvein strong, reaching nearly to the apex of the pinnule. Lateral veins departing at an acute angle, reaching the margin perpendicularly, forking two or three times, with first bifurcation close to the midvein, and the second about half way between the midvein and the margin, often directly following the major curvature of the veins; the third, if present, near the margin. (Shortened from Goubet et al. 2000, p. 14.)

Remarks. Neuralethopteris is a widely distributed and biostratigraphically important genus that has been recorded from middle Namurian to lower Westphalian strata. The presence of pinnules with alethopterid venation in combination with basally constricted bases caused most species to be initially assigned to Neuropteris.

Laveine (1967) and Tenchov and Cleal (2010) summarized the historical development of the concept of Neuralethopteris; and Goubet et al. (2000) documented the genus for the first time in North America, including five species not found in Europe. Furthermore, Laveine et al. (1992) recorded the presence of a bipartite frond without intercalary pinna elements on the rachises, as in Alethopteris, and indicated that the frond would be about $5 \mathrm{~m}$ long. Associated ovules are of the Trigonocarpus-type and pollen organs are of the Aulacotheca/Boulayatheca/Whittleseya-types.

According to Wagner (1984), Neuralethopteris is common and characteristic in both the Neuralethopteris larischii-Pecopteris aspera (Chokierian to Yeadonian) and Lyginopteris hoeninghausii-Neuralethopteris schlehanii (Langsettian) macrofloral zones. Although some records occur in the basal Duckmantian (e.g., Tenchov and Cleal 2010), the extinction of Neuralethopteris is usually placed at the end of the Langsettian Substage. 
Neuralethopteris pocahontas (White 1900)

Goubet et al. 2000

(Figs. 8a-d)

* 1900 Neuropteris Pocahontas White, p. 888-890, pl. CLXXXIX, figs. 4-4a; pl. CXCI, figs. 5-5a (holotype).

1900 Neuropteris Pocahontas var. incequalis White, p. 890-892, pl. CLXXXVIII, figs. 5-5a; pl. CXC, fig. 7; pl. CXCI, figs. 1-4 (acc. to Goubet et al. 2000).

1937 Neuropteris Pocahontas White; Jongmans, p. 396, 397, 398, 400, 412; pl. 13, figs. 15-15a; pl. 14, figs. 16-20a; pl. 16, fig. 27; pl. 17, fig. 30 .

1944 Neuropteris smithsi Lesquereux; Bell, p. 79-80, pl. XXIX, fig. 2; pl. XXX, fig. 2 (reproduced partially herein as Fig. 8d); pl. XXXI, fig. 1 (Figs 8b-c herein), fig. 4; pl. XXXIII, fig. 3 (Fig. 8a herein), fig. 4; pl. LXVII, fig. 4.

1964 Neuropteris pocahontas White; Read and Mamay, p. 6, pl. 4, fig. 2.

1966 Crossotheca pinnatifida (Gutbier) Potonié; Bell, p. 16, pl. IV, fig. 1 .

1966 Neuropteris pocahontas White; Gillespie et al., p. 90,91 , pl. 25, fig. 4 ; non pl. 25, figs. 2-3 (comparable with Neuralethopteris sergiorum).

? 1967 Neuropteris cf. pocahontas White; Tidwell, p. 43, pl. 5, figs. 4,6 .

1976 Neuropteris pocahontas White; Gillespie and Pfefferkorn, pl. I, figs. A, B.

1977 Neuropteris pocahontas White; Pfefferkorn and Gillespie, p. 23, pl. 2, fig. J (same as Gillespie and Pfefferkorn 1976, pl. I, fig. A), pl. 2, figs. $\mathrm{K}-\mathrm{L}$.

1978 Neuropteris pocahontas White; Gillespie et al., p. $6,7,102-103,115,128$, pl. 2, fig. 1 (same as Pfefferkorn and Gillespie 1977, pl. 2, fig. L); pl. 47, fig. 1 (same as Gillespie et al. 1966, pl. 25, fig. 4), fig. 2 (same as Pfefferkorn and Gillespie 1977, pl. 2, fig. K), fig. 3 (same as Gillespie and Pfefferkorn 1976, pl. I, fig. A, and Pfefferkorn and Gillespie 1977, pl. 2, fig. J), fig. 5 (same as Pfefferkorn and Gillespie 1977, pl. 2, fig. L), figs. 7-8.

1979 Neuropteris pocahontas White; Gillespie and Pfefferkorn, pl. 1, fig. 1.

1981 "Neuropteris pocahontas" White; Pfefferkorn and Gillespie, p. 160, 162, pl. 2, figs. 1-4.

? 1985 Neuropteris (Neuralethopteris) pocahontas White; Gastaldo, p. 292, pl. 3, fig. C (poorly figured).

1986 Neuropteris pocahontas White; Gillespie and Pfefferkorn, p. 127, 128, pl. 3, fig. 1 (same as Pfefferkorn and Gillespie 1981, pl. 2, fig. 3), pl. 3, fig. 2 (same as Gillespie and Pfefferkorn 1979, pl. 1, fig. 1).

1989 Neuropteris pocahontas White; Gillespie et al., p. 5, 6, pl. 1, fig. 3 (same as Gillespie and Pfef- ferkorn 1976, pl. I, fig. A, and Gillespie et al. 1978, pl. 47, fig. 3).

1997 Neuropteris (Neuralethopteris) pocahontas White; Blake, p. 81, 83, 84, pl. 4, figs. 1-2; pl. 6, fig. 5; pl. 7, fig. 1.

$\S \mathrm{T} 2000$ Neuralethopteris pocahontas (White) Goubet et al., p. 18-19 (including synonymy), figs. 5.3-5.6; fig. 6 (drawing); fig. 7.3 (photograph of White's holotype); figs. 7.4-7.5 (same as White 1900, pl. CLXXXVIII, figs. 5-5a); figs. 7.6-7.7; fig. 17.10 (associated with seeds).

2002 Neuralethoperis pocahontas (White) Goubet et al.; Blake et al., p. 268, pl. XIV, figs. 3-4; pl. XV, fig. 9 (same as Pfefferkorn and Gillespie 1977, pl. 2, fig. L, and Gillespie et al. 1978, pl. 47, fig. 5).

2005 Neuralethopteris pocahontas (White) Goubet et al.; Dilcher et al., p. 163, fig. 4.5.

2005 Neuralethopteris pocahontas (White) Goubet et al.; Dilcher and Lott, pl. 134, fig. 2 (same as Dilcher et al. 2005, fig. 4.5); pl. 135, fig. 3; pl. 136, fig. 3 (difficult to judge from the illustration).

Description. Frond at least bipinnate. Penultimate order rachis straight, longitudinally striate, ca. $0.75 \mathrm{~mm}$ wide. Last order pinnae subrectangular, inserted at $60-80^{\circ}$. Last order rachis straight, rounded, longitudinally striate, ca. $0.25 \mathrm{~mm}$ wide. Pinnules alternate, closely spaced, either oblong, with cordate base, or rounded and broadly attached to the rachis. Dimensions: up to $30 \mathrm{~mm}$ long and $6-8 \mathrm{~mm}$ broad. Lamina thick, vaulted. Venation well-marked; in the smaller pinnules the midrib is not clearly differentiated and lateral veins, up to two times forked, depart directly from the rachis; in larger, more elongate pinnules the straight midrib extends in the lower two thirds of the pinnule and lateral veins are two (rarely three) times forked. Vein density $=\mathrm{ca}$. 55 veins per centimetre.

Remarks. Neuralethopteris pocahontas is a very variable species that, according to Gillespie et al. (1978), grades morphologically into Neuralethopteris smithsii. Although Goubet et al. (2000) also noted that it is difficult to distinguish these two species in eastern North America, they did not follow Williams's (1937) proposal to synonymize the two taxa (along with Neuralethoperis schlehanii), citing stratigraphic and geographic differences.

I include in Neuralethopteris pocahontas all the specimens from Nova Scotia previously figured and described by Bell (1944) as Neuropteris smithsii and that figured by Bell (1966) as Crossotheca pinnatifida (= Remia pinnatifida - an upper Stephanian species). Bell (1944) records Neuralethopteris smithsii from 18 localities, but all his figured specimens are from locality 1392, Inverness County, Cape Breton Island. This focus is possibly due to poor and/or fragmentary preservation in all other localities, an explanation supported by the fact that most of the material that I have reviewed is very fragmentary. 
Neuralethopteris pocahontas is usually recorded from fragmentary ultimate or penultimate order pinnae, thus preventing an understanding of its frond architecture.
Comparisons. Larger, more elongate pinnules of both Neuralethopteris pocahontas and Neuralethopteris smithsii have similar size and shape; but lateral veins in the latter reach the
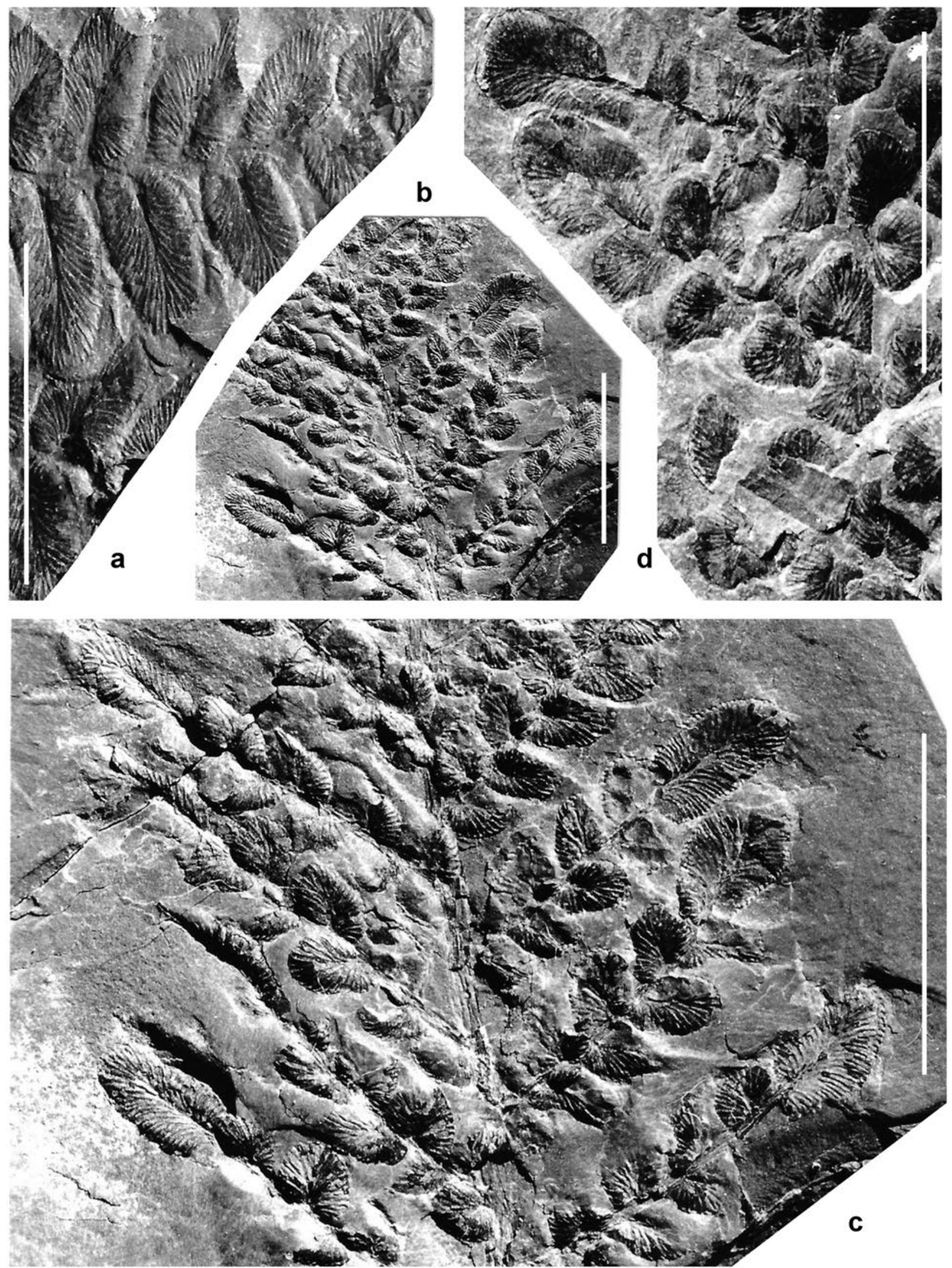
pinnule margin at approximate right angles, in contrast to an obtuse angle in Neuralethopteris pocahontas. In addition, the smallest pinnules of Neuralethopteris pocahontas do not show a clearly differentiated midrib, and veins emanate directly from the rachis. Neuralethopteris pocahontas has superficial similarities with some specimens of the recently described Wagneropteris minima. The latter also has ovoid to subrectangular pinnules, commonly attached by a short, broad stalk; but the first anadromous and catadromous pinnules of last order pinnae are shorter than the standard laterals, allowing space for intercalary pinnules on the penultimate rachis.

Stratigraphic and geographic distribution. Goubet et al. (2000) recorded Neuralethopteris pocahontas as very common in lower Langsettian strata of the Pocahontas Formation in West Virginia, occurring in nearly all known plant fossil localities. The type material is from Pottsville, Southern Anthracite Field, Appalachian Basin, where Blake et al. (2002) reported the species as endemic. Prior to the present work, Neuralethopteris pocahontas has been reported only from the United States.

Occurrence in the Maritime Provinces, Canada. CumberLAND BASIN (Nova Scotia): Bell (1944): locality 1392 (GSC 3089 + GSC 9361 + GSC 9362 + GSC 9363 + GSC 9365); New Brunswick: Bell (1966): locality 887 (GSC $6627+$ GSC 6632 + GSC 6638 + GSC 6639 + GSC 6643 + GSC 6644 + GSC 15040).

Occurrence in the United States. Alabama: White (1900), Gastaldo (1985), Gillespie and Rheams (1985), Dilcher and Lott (2005), Dilcher et al. (2005). Georgia: Gillespie and Pfefferkorn (1976), Pfefferkorn and Gillespie (1977), Gillespie et al. (1978), Gillespie et al. (1989). Pennsylvania: White (1900), Goubet et al. (2000). UTAH: Tidwell (1967). VIrginia: Pfefferkorn and Gillespie (1977), Gillespie et al. (1978), Gillespie and Pfefferkorn (1979), Pfefferkorn and Gillespie (1981), Gillespie and Pfefferkorn (1986), Blake et al. (2002). West Virginia: White (1900), Read and Mamay (1964), Gillespie et al. (1966), Pfefferkorn and Gillespie (1977), Gillespie et al. (1978), Pfefferkorn and Gillespie (1981), Gillespie and Pfefferkorn (1986), Blake (1997), Goubet et al. (2000).

\footnotetext{
Neuralethopteris schlehanii (Stur 1877) Cremer 1893 (Figs. 9a-d)

*? $1871 \quad$ Neuropteris Selwyni Dawson, p. 50, pl. XVII,
}

fig. 198 (schematic drawing — synonymy first proposed by Stopes 1914).

* $1877 \quad$ Neuropteris Schlehani Stur, p. 289 [183], Taf. XI [XXVIII], figs. 7-8c.

* $1877 \quad$ Neuropteris Dluhoschi Stur, p. 289 [183]-290 [184], Taf. XI [XXVIII], fig. 9 (acc. to Zeiller 1888).

1877 Neuropteris microphylla Brongniart; Heer, p. 24, Taf. V, fig. 6a; Taf. VI, figs. 1-9.

${ }^{*}$ p 1879-84 Neuropteris Elrodi Lesquereux, p. 107-108, pl. XIII, fig. 4 (acc. to Zeiller 1888); non p. 735-736, pl. XCVI, figs. 1-2 (= Neuralethopteris biformis acc. to Goubet et al. 2000).

$\S 1893$ Neuralethopteris Schlehani (Stur) Cremer, p. 33 .

? $1914 \quad$ Neuropteris Selwyni Dawson (? Neuropteris Schlehani Stur); Stopes, p. 64-66, pl. XV, fig. 37 (photograph of Dawson's holotype fragmentary and poorly preserved); text-fig. 12 (drawing).

1934 Neuropteris dluhoschi Stur; Read, p. 81, 83-84, pl. 17, fig. 5.

1937 Neuropteris Schlehani Stur; Jongmans, p. 402, 403, 412, pl. 21, fig. 44; pl. 22, figs. 48-49 (together with Aulacotheca).

1941 Neuropteris Dluhoschi Stur; Arnold, p. 59, pl. I, figs. 3-4.

v $1944 \quad$ Neuropteris schlehani Stur; Bell, p. 79, pl. XXX, fig. 3; pl. XXXII; pl. XXXIII, figs. 5-6.

1947 Neuropteris Schlehani Stur; Arnold, p. 220, fig. 105B.

1949 Neuropteris Schlehani Stur; Arnold, p. 199-201, pl. XXIV, fig. 7 (same as Arnold 1947, fig. 105B), figs. 8, 9; pl. XXIV, fig 10.

* 1952a-53 Neuropteris schlehanoides Stockmans and Willière, p. 233, pl. XXXI, figs. 3-3a, 7y; pl. XXXVI, fig. 2 (acc. to Cleal and Shute 1995).

1957 Neuropteris schlehani Stur; Leggewie and Schonefeld, p. 13-15, Taf. 4, Abb. 1-5; Taf. 5, Abb. 1-4; Taf. 6, Abb. 1-4; Taf. 7, Abb. 1.

1960 Neuropteris parvifolia Stockmans; Jongmans, p. 61, Taf. 23, figs. 127-127a (photograph of Heer's 1877, Taf. VI, fig. 3), figs. 128-128a (same as Heer, 1877, Taf. VI, fig. 4), figs. 129-130a.

v $1966 \quad$ Neuropteris schlehani Stur; Bell, pl. IV, fig. 7 (counterpart of Bell 1944, pl. XXXIII, fig. 5), fig. 12; pl. V, fig. 9; pl. VI, fig. 5 (same as Bell

Figure 8 (previous page). (a) Neuralethopteris pocahontas. GSC 3089. Detail of the specimen figured as Neuropteris smithsii by Bell (1944, pl. XXXIII, fig. 3). Origin: Whale Cove, Inverness County, about $0.4 \mathrm{~km}$ south of Grey Point (locality 1392). (b) Neuralethopteris pocahontas. GSC 9361. Penultimate order pinna closely similar, although with smaller pinnules, to White's holotype. As Neuropteris smithsii in Bell (1944, pl. XXXI, fig. 1; pl. LXVII, fig. 4). Origin: same as Fig. 8a (locality 1392). (c) Neuralethopteris pocahontas. Enlargement of Fig. 8b. Note the thick, vaulted lamina and lateral veins departing directly from the rachis. (d) Neuralethopteris pocahontas. GSC 9362. As Neuropteris smithsii in Bell (1944, pl. XXX, fig. 2). Origin: same as for Figs. 8a-8c (locality 1392). Repository: Geological Survey of Canada, Ottawa. Scale bar $=1 \mathrm{~cm}$. 

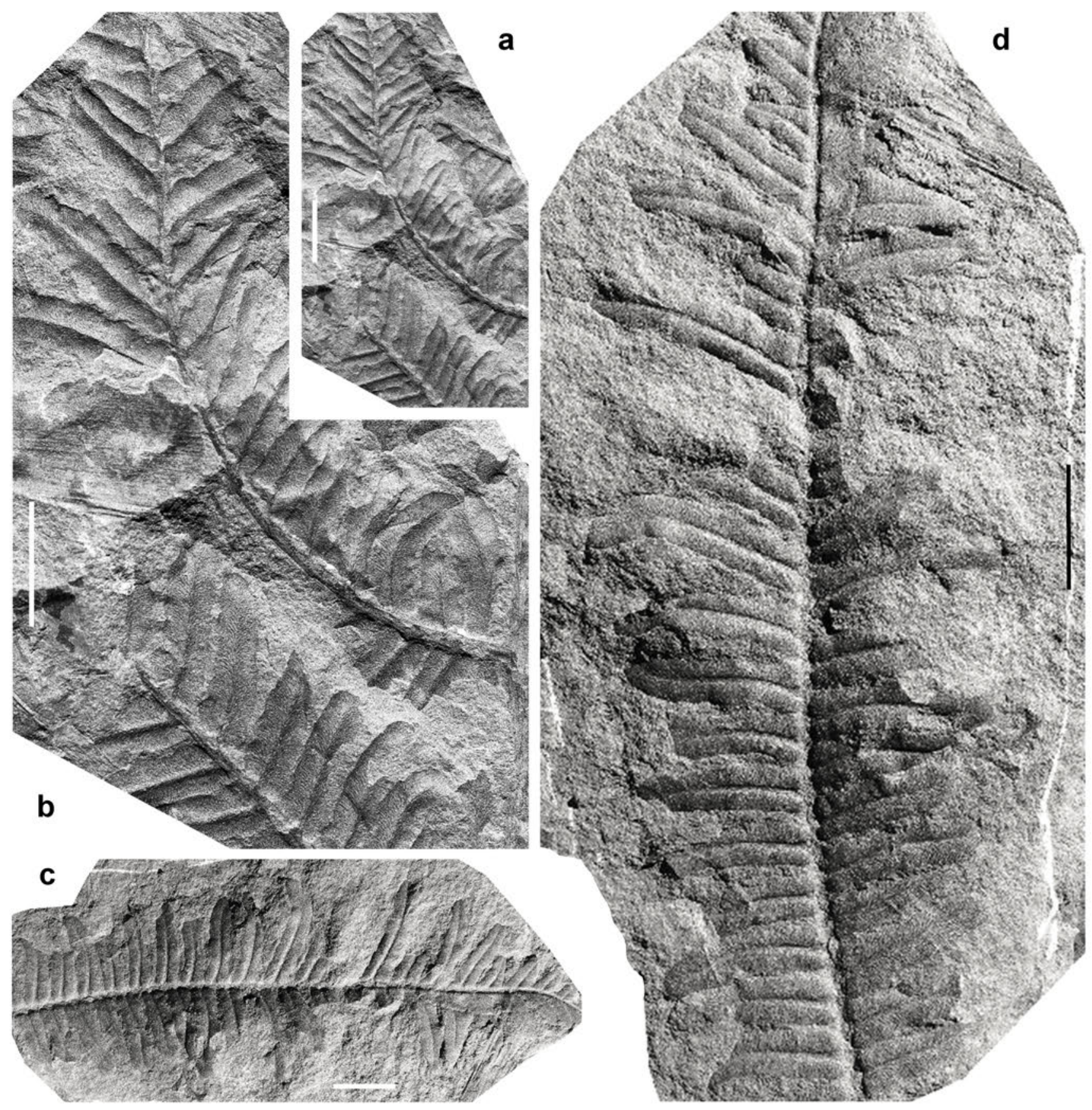

Figure 9. (a) Neuralethopteris schlehanii. GSC 10959. Previously figured by Bell (1944, pl. XXXIII, fig. 5). Origin: Cape Maringouin, south of Hard Ledge, New Brunswick (loc. 1357). (b) Enlargement of Fig. 9a. (c) Neuralethopteris schlehanii. GSC 10958. Last order pinna showing the larger, most characteristic pinnules: subrectangular, with subparallel margins, obtuse apex and cordate base. Figured by Bell (1944, pl. XXXIII, fig. 6). Origin: same as Figs. 9a-9b. (d) Enlargement of Fig. 9c. Repository: Geological Survey of Canada, Ottawa. Scale bar $=1 \mathrm{~cm}$.

1944, pl. XXXII).

1967

Neuralethopteris schlehani (Stur) Cremer; Laveine, p. 113-120 (including synonymy), pl. V, figs. 1-3b; pl. VI, figs. 1-4; pl. VII, figs. 1-3a; pl. VIII, figs. 1-4a; text-fig. 18.

* 1977 Neuropteris rectinervis f. obtusa Tenchov, p. 59-60, Taf. XX, figs. 3-4 (acc. to Cleal and Shute 1995).
* 1977

* 1977
Neuropteris lata Tenchov, p. 60, Taf. XXI, figs. 2-3 (acc. to Cleal and Shute 1995).

Neuropteris longifolia Tenchov, p. 61, Taf. XXI, figs. 4-7, 9 (acc. to Cleal and Shute 1995) (all specimens figured and described by Tenchov as Neuropteris rectinervis f. obtusa, Neuropteris lata and Neuropteris longifolia originated from localities where that author 
also records Neuralethopteris schlehanii).

1984 Neuropteris schlehani Stur; Jennings, p. 307, pl. 4 , fig. 1.

p 1985 Neuralethopteris schlehani (Stur) Cremer; Lyons et al., p. 232, pl. VI, figs. c-d; pl. XI, fig. d; non pl. XIV, fig. c (= Neuralethopteris biformis acc. to Goubet et al. 2000).

1985 Neuralethopteris schlehani (?) (Stur) Cremer; Lyons et al., p. 232-233, pl. X, fig. c.

1985 Neuropteris pocahontas cf. var. inaequalis White; Lyons et al., p. 219, pl. VI, fig. g (acc. to Goubet et al. 2000).

1985 Neuropteris cf. schlehani Stur; Gillespie and Crawford, p. 252, 255, pl. III, fig. 7.

1985 Neuropteris pocahontas White; Gillespie and Rheams, p. 194, 196, 199, pl. II, fig. 7 (acc. to Goubet et al. 2000).

1995 Neuralethopteris schlehanii (Stur) Cremer; Cleal and Shute, p. 24 (including synonymy), fig. 8 (p. 13).

1996 Neuralethopteris schlehanii (Stur) Cremer; Brousmiche Delcambre et al., p. 83, pl. 3, figs. 3-6a; pl. 7, figs. 1-8; pl. 8, figs. 1-3; pl. 10 , fig. 11.

1997 Neuralethopteris schlehanii (Stur) Cremer; Blake, p. 84, 85, 90, pl. 3, fig. 8; pl. 8, figs. $1-2$; pl. 9, fig. 5; pl. 10, fig. 2.

$1998 \quad$ Neuralethopteris schlehanii (Stur) Cremer; Brousmiche Delcambre et al., p. 106-107, pl. 12, figs. 1-12; pl. 13, figs. 1-4.

2000 Neuralethopteris schlehani (Stur) Cremer; Goubet et al., p. 15-18 (including synonymy), figs. 4.1-4.2; figs. 5.1-5.2, 5.7-5.8.

2002 Neuralethopteris schlehanii (Stur) Cremer; Blake et al., p. 264, 268, 269, pl. XV, figs. 7-8.

p $2002 \quad$ Neuropteris bulupalganensis Zalessky; Blake et al., p. 263, 289, pl. XIII, fig. 9; non p. 288, pl. XIII, fig. 3 (= Senftenbergia aspera).

2010 Neuralethopteris schlehanii (Stur) Cremer; Tenchov and Cleal, p. 301, 303, pl. I, figs. $1-2$.

V 2010

Neuralethopteris schlehanii (Stur) Cremer; Wagner and Álvarez-Vázquez, p. 254, 257, 258, pl. VI, fig. 1.

2014 Neuralethopteris schlehanii (Stur) Cremer; Bashforth et al., p. 247, pl. III, figs. 2, 5, 8.

2018 Neuralethopteris schlehanii (Stur) Cremer; Lyons and Sproule, p. 319, figs. 3a-b.

Excludenda:

1985 Neuropteris schlehani Stur; Gillespie and Rheams, p. 194, 196, 199, pl. II, figs. 9-10 (= Neuralethopteris biformis acc. to Goubet et al. 2000).

Description. Frond at least bipinnate. Penultimate order pinnae apparently lanceolate, with an approximately constant width in the lower three quarters, then quickly taper- ing to form an acute apex. Dimensions: up to $160 \mathrm{~mm}$ long and $150 \mathrm{~mm}$ wide. Penultimate order rachis straight, longitudinally striate, ca. $1.25-1.50 \mathrm{~mm}$ wide. Last order pinnae alternate, closely spaced or slightly touching each other by their margins; subrectangular, elongate, with subparallel margins; apical pinnule lanceolate to oval, small but longer than the adjacent laterals. Dimensions: $30-110 \mathrm{~mm}$ long and $6-15 \mathrm{~mm}$ wide; length/breadth ratio $=5-6.5$. Last order rachis inserted at $50-75^{\circ}$, longitudinally striate, rounded, ca. 0.5-0.75 mm. Pinnules alternate, close, subperpendicular or obliquely inserted $\left(45-60^{\circ}\right)$, of fairly constant size along the pinna; the larger ones are subrectangular, elongate, with subparallel margins, obtuse apex and cordate base, attached to the rachis throught a short stalk; smaller pinnules are subtriangular to ovoid, with cordate base, except in the apical parts of pinnae where they are more broadly united to the rachis. Dimensions: 4-14 mm long and 1.5-3.5 mm broad; length/breadth ratio $=2.5-4$. Lamina thick, vaulted. Venation clearly marked. Midrib thick, straight, distinct in the lower three quarters of the pinnule length. Lateral veins thin, usually twice forked, the first fork occurring near the midrib, the second about half-way between the midrib and the margin; lateral veins reaching the pinnule margin with $75-85^{\circ}$. Vein density $=40-50$ veins per centimetre.

Remarks. Specimens figured as Neuropteris schlehanii by Bell $(1944,1966)$ confirm the presence of this species in the Maritime Provinces. This is particularly the case for the well-preserved terminal of antepenultimate order pinna figured from the roof shales of coal $n^{\circ} 1$ at Springhill, Nova Scotia (Bell 1944, pl. XXXII; Bell 1966, pl. VI, fig. 5), which shows the characteristic medium-sized pinnules with cordate base, broadly rounded apex and subparallel margins. Neuralethopteris schlehanii is found also in association with White's Whittleseya brevifolia (male synangium) in several localities.

Dawson's (1871) fragmentary type of Neuropteris selwynii, a poorly preserved fragment of last order pinna show-ing only four pinnules, was photographically illustrated by Stopes (1914, pl. XV, fig. 37), who suggested its synonymy with Neuropteris schlehanii. This synonymy was accepted by Bell (1944) who stated that Dawson's Neuropteris selwynii is merely an "aberrant" form of Neuropteris schlehanii. Bell (1944) also included Kidston's Neuropteris rectinervis (= Neuralethopteris rectinervis) in synonymy with Neuro-pteris schlehanii. In contrast, Laveine (1967) includes Stopes's illustration of Neuropteris selwynii in the synonymy of Neuralethopteris rectinervis; and Tenchov and Cleal (2010) compare the venation pattern of Neuropteris selwynii with that of Neuralethopteris jongmansii.

I have not been able to review Dawson's holotype of Neuropteris selwynii, so it is only questionably included in the synonymy of Neuralethopteris schlehanii. If it were proved that Neuropteris selwynii and Neuralethopteris schlehanii are cospecific, Dawson's name would take priority. Although Stur's type material of Neuropteris schlehanii is also fragmentary, consisting three fragments 
of last order pinnae without apical pinnules, the use of the name Neuralethopteris schlehanii should justify the proposal for conservation of the latter name should the synonymy be confirmed (see also Tenchov and Cleal 2010).

Comparisons. The larger pinnules of both Neuralethopteris pocahontas and Neuralethopteris schlehanii are similar. However, the smaller pinnules - rounded, broadly attached to the rachis and without clearly differentiated midvein - are common and characteristics in Neuralethopteris pocahontas but absent in Neuralethopteris schlehanii. Neuralethopteris jongmansii has longer and broader pinnules and more regular venation, both in terms of curvature and density. Pinnules of Neuralethopteris biformis are more subtriangular, with margins gradually tapering in the distal two thirds. In addition, the venation Neuralethopteris biformis is coarse, with lateral veins twice or occasionally three-times forked, reaching the margin at an angle of about $60^{\circ}$.

Stratigraphic and geographic distribution. Neuralethopteris schlehanii is the most abundant and widely distributed species of Neuralethopteris over the paleoequatorial belt. It ranges in age from upper Namurian A to basal Duckmantian. The type material is from Vítkovice, Upper Silesian Basin, Czech Republic (Stur 1877). The species is common in Langsettian strata of Great Britain (Crookall, 1955). In France, Laveine (1967) recorded it from Westphalian A (Langsettian) strata of Nord/Pas-de-Calais, and Brousmiche Delcambre et al. $(1996,1998)$ from the Namurian B and C of Briançon. The species was recorded in Belgium from the upper part of the Namurian A up to the top of Westphalian A (Langsettian; Stockmans and Willière 1952a-53, 1952b). In the Iberian Peninsula, Wagner and Álvarez-Vázquez (2010) recorded Neuralethopteris schlehanii from middle Namurian strata of the central Pyrenees, from the upper Namurian of La Camocha Coalfield of northwestern Spain, from the Langsettian of different localities in the Cantabrian Mountains of northwestern Spain, and from upper Langsettian strata of the Peñarroya-Belmez-Espiel Coalfield of southwestern Spain. Tenchov and Cleal (2010) reported the species in Langsettian and basal Duckmantian strata of the Dobrudzha Coalfield of Bulgaria.

Occurrence in the Maritime Provinces, Canada. Cumberland Basin (Nova Scotia): Bell (1944): locality 187 (four pieces without catalogue number - cf.; fragmentary); local-ity 876 (GSC 5929 - together with one seed); locality 1337 (GSC 10957); locality 1354 (GSC 10960); locality 1357 (GSC 10958 + GSC 10959). Bell (1966): locality 1337 (GSC 10957 - same as 1944); locality 1357 (GSC 14955 + GSC 14946). New Brunswick: Bell (1944): locality 793 (one piece without catalogue number- fragmentary); locality 3557 (one piece without catalogue number). Bell (1966): locality 1429 (GSC 14954). Dawson (1871): as Neuropteris selwyni - included questionably in the synonymy. Stopes (1914): same as Dawson (1871). New BRunswick Museum COllection: NBMG 12052/1 (together with Sphenopteris valida). Bash-forth et al. (2014): NBMG 15438 + NBMG 16196 + NBMG 16218a).

Occurrence in the United States. Alabama: Lesquereux (1879-80), Gillespie and Rheams (1985), Lyons et al. (1985), Goubet et al. (2000). Colorado: Read (1934), Arnold (1941). Georgia: Lesquereux (1884), Gillespie and Crawford (1985). IllinoIs: Jennings (1984). IndianA: Lesquereux (1879-80). MassachusetTs: Lyons and Sproule (2018); Michigan: Arnold (1947, 1949). West Virginia: Jongmans (1937), Goubet et al. (2000), Blake (1997), Blake et al. (2002).

Neuralethopteris smithsii (Lesquereux 1879)

Goubet et al. 2000

(Figs. 10a-d)

*? $1831 \quad$ Neuropteris microphylla Brongniart, p. 245, pl. 74, figs. 6-6a (reproduction of Brongniart illustration, as Neuropteris heterophylla, by Crookall 1959, text-fig. 35).

* 1879-84 Neuropteris Smithsii Lesquereux, p. 106-107, 734-735, pl. XIII, fig. 1, fig. 2 (lectotype designated by Goubet et al. 2000), figs. 3-3a; pl. XCVI, figs. 3-3a.

1905 Neuropteris cf. Smithii Lesquereux; White, p. 380, pl. LV (magnificent specimen antepenultimate order pinna, more than 50 cm long).

1926 Neuropteris smithii Lesquereux; Butts, p. 224, pl. 70C, figs. 1-3.

1937 Neuropteris Smithsii Lesquereux; Jongmans, p. 400, 401, 404, 412, pl. 20, figs. 42-43.

${ }^{*}$ v 1944 Sphenopteris minuscula n. sp. Bell, p. 63-64, pl. VI, figs. 1, 3-5; pl. X, fig. 5; pl. XI; pl. LXVI, figs. 4-5.

? p $1967 \quad$ Neuropteris rarinervis Bunbury; Laveine, pl. G, figs. 2-2a (photograph of the holotype of Neuropteris microphylla); text-fig. 31d; non p. 181-190, pls. XL-XLVII (= Laveineopteris rarinervis); text-figs. 31a-c, e-i (drawings of Laveineopteris rarinervis).

1979 Neuropteris smithsii Lesquereux; Gillespie and Pfefferkorn, pl. 1, figs. 5-6.

? $1985 \quad$ Neuropteris (?Neuralethopteris) smithsii Lesquereux; Gastaldo, p. 292, pl. 3, fig. B (poorly figured).

1985 Neuropteris smithi (sic) Lesquereux; Gillespie and Rheams, p. 196, pl. I, fig. 1.

1985 Neuropteris smithsii Lesquereux; Lyons et al., p. 234, pl. II, figs. A-C, fig. E (? - fragmentary, isolated pinnule); pl. VI, figs. a-b; pl. X, figs. a-b.

1985 Neuropteris smithi (sic) Lesquereux; Gillespie and Crawford, p. 252, pl. II, fig. 6.

$\S 2000 \quad$ Neuralethopteris smithsii (Lesquereux) Goubet et al., p. 19-23 (including synonymy), figs. 7.1-7.2; figs. 8.1-8.2 (drawings); 

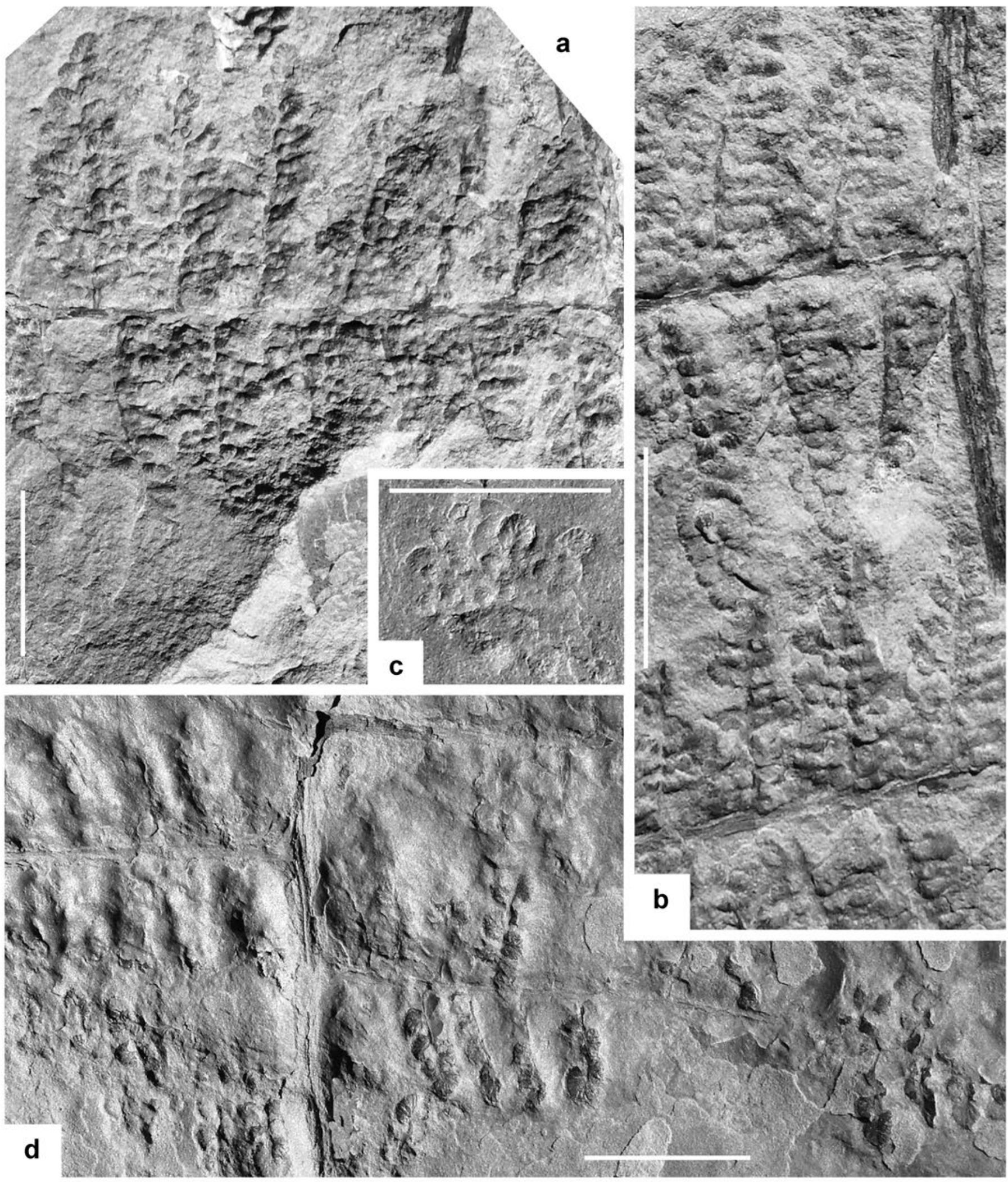

Figure 10. (a) Neuralethopteris smithsii. GSC 5857. Lower part of the holotype of Sphenopteris minuscula (Bell 1944, pl. XI). Origin: East Branch River Philip, Oxford area, Nova Scotia (locality 860). (b) Detail of the holotype. Note the close similarity to the specimen figured by Goubet $e$ t al. (2000, figs. 7.1 and 7.2). Origin: same as Fig. 11a. (c) GSC 5853. Paratype of Sphenopteris minuscula. Previously figured by Bell (1944, pl. VI, figs 1, 5). Origin: same as Figs. 11a-11b. (d) GSC 5593. Another paratype of Sphenopteris minuscula. Figured by Bell (1944, pl. X, fig. 5). Origin: same as Figs. 11a-11c. Repository: Geological Survey of Canada, Ottawa. Scale bar $=1 \mathrm{~cm}$. 
figs. 9.1-9.4; figs. 15.5-15.7 (together with Aulacotheca prepollen organs).

2002 Neuralethopteris smithsii (Lesquereux) Goubet et al.; Blake et al., p. 264, 267, 268, pl. XIV, fig. 7; pl. XV, fig. 1; pl. XVIII, fig. 4.

Description. Frond at least tripinnate. Antepenultimate order rachis straight, longitudinally striate, ca. $4 \mathrm{~mm}$ wide. Penultimate order pinnae alternate, apparently subtriangular (always incomplete), with at least $85 \mathrm{~mm}$ long and up to $55 \mathrm{~mm}$ wide. Penultimate order rachis inserted at $85-90^{\circ}$, straight, longitudinally striate, ca. $1.5-2 \mathrm{~mm}$ wide. Last order pinnae alternate, subtriangular, elongated, inserted at 80 $90^{\circ}$. Pinna terminal relatively large, massive-looking in pinnae with smaller (shorter) pinnules, more elongate in those with larger (longer) pinnules. Dimensions: up to $16 \mathrm{~mm}$ long and 6-7 mm wide. Last order rachis inserted at $80-90^{\circ}$, straight, ca. $0.4-0.5 \mathrm{~mm}$. Pinnules alternate, subperpendicularly inserted, ovate or rounded, with cordate base even in distal parts. Dimensions: 2-6 mm long and 1.5-2.5 mm wide; length/breadth ratio $=1.3-2.4$. Lamina thick, vaulted. Venation well marked, widely spaced. Midrib thin, deeply imprinted in the convex lamina. Lateral veins thin, oblique, twice forked, the first time near the midrib; lateral veins reaching the margin at aproximately right angle. Vein density $=30-32$ veins per centimetre.

Remarks. Both Bell (1944) and Laveine (1967) suggested the inclusion of Neuropteris smithsii with Neuralethopteris on the basis of its fairly constant association with the prepollen-bearing synangium Whittleseya desiderata, a species figured and described from Nova Scotia by White (1901, pl. VII, figs. 1-2). In the same paper, White figured and described another two species, Whittleseya brevifolia (pl. VII, figs 3-3a) and Whittleseya dawsoniana (pl. VII, figs. 4-4a), based on specimens from Nova Scotia and New Brunswick, respectively. To confirm or discard the possible synonymy of part or of all these taxa, the palynological content of these species should be studied, along with that of Whittleseya concinna (and its varieties, Whittleseya concinna var. lata and Whittleseya concinna var. arcta), which was described by Matthew (1910) from the Fern Ledges.

Goubet et al. (2000) formally transferred Neuropteris smithsii to Neuralethopteris. Neuralethopteris smithsii was analyzed extensively by Goubet et al. (2000), who reviewed the occurrence of Neuralethopteris in eastern North America. These authors designated as lectotype the specimen figured by Lesquereux (1880, pl. XIII, fig. 2). Goubet et al. (2000) did not compare Neuralethopteris smithsii with Neuropteris microphylla, a species described by Brongniart in 1831 from a single specimen from Wilkesbarre, Pennsylvania, in the same general area (the Appalachian Basin) as the type material of Neuralethopteris smithsii. I think that Brongniart's specimen, photographed by Laveine (1967, pl. G, figs. 2-2a), who included it in Neuropteris rarinervis (now Laveineopteris rarinervis), fits the shape and dimensions of Neuralethopteris smithsii. Even though Laveine's photograph does not show the venation - Stockmans 1933 examined the type of Neuropteris microphylla and noted that its venation is not well preserved - I consider the resemblance so close that I include Neuropteris microphylla questionably in synonymy with Neuralethopteris smithsii. Should this synonymy be confirmed, the widespread use of the name Neuralethopteris smithsii should justify the proposal for its conservation. Neuropteris microphylla was consistently misidentified in Europe until Stockmans (1933) described the European form as a new species, Neuropteris parvifolia.

Bell (1944) described and illustrated Sphenopteris minuscula from several poorly preserved specimens and compared it with Sphenopteris nummularia and Sphenopteris hollandica (both now in Eusphenopteris) and Neuropteris smithsii. He thus appeared in no doubt that the attribution of Sphenopteris minuscula was to the pteridosperms. Although Bell mentioned three different localities for this new species, all figured specimens, including the holotype, came from locality 860 in Nova Scotia. (In the plate caption, the holotype was wrongly indicated as having come from locality 1392 , although this site was not mentioned in the description of Sphenopteris minuscula.) Bell's specimens are impressions on siltstone to fine grained sandstones. Because of the combination of the coarseness of the sediment grain and the vaulted lamina, the exact outline of pinnules and venation is rarely discernible, making detailed observation and photography difficult. No subsequent records of Sphenopteris minuscula are known. I regard Neuralethopteris smithsii as the senior synonym of Sphenopteris minuscula.

At first sight, Sphenopteris minuscula could be also compared with several species of Margaritopteris. Gothan (1913) based that genus on Margaritopteris pseudocoemansii, a species that Laveine et al. (1977, p. 783) regarded as synonymous with Margaritopteris conwayi. In the latter extensive paper, Margaritopteris is placed in a series leading from the lower Namurian Neuropteris multivenosa (a species later referred to Margaritopteris by Cleal and Shute 1995) through Margaritopteris of Westphalian age to Praecallipteridium and Callipteridium of upper Asturian to Stephanian age. In this view, progressive reduction of elements of a large frond and fusion of pinnular elements lead from intercalated pinnae to intercalated pinnules on ante-penultimate and penultimate rachises and to larger, fused pinnules in Praecallipteridium and Callipteridium. The most complete documentation of Margaritopteris conwayi is by Crookall (1976), who figured a large antepenultimate pinna fragment more than $24 \mathrm{~cm}$ long from Duckmantian strata of South Wales. Crookall's illustration shows that Margaritopteris pinnules are united to each other and attached to the rachis by the whole base. In addition, veins are undivided and the faintly longitudinally striate rachis usually bears close transverse bars. None of these characteristics are present in Sphenopteris minuscula.

Although European authors have shown an awareness of Neuropteris smithsii, this species has not been recorded as such from Europe.

Comparisons. Larger pinnules of Neuralethopteris pocahon- 
tas possess similar size and shape to those of Neuropteris smithsii. However, the smallest pinnules of the former species do not show a clear differentiated midrib: several parallel veins originate directly from the rachis, forking twice. Although the midrib is more clearly marked in elongated pinnules, some veins enter directly from the pinna axis, and lateral veins reach the margins at obtuse angles, not at right angles as in Neuralethopteris smithsii. Some similarity exists between Neuropteris smithsii and Neuralethopteris weilii (Josten and Amerom 2003), a species from middle Namurian strata of Westphalia, western Germany. Pinnules of the latter species are small, oval to subrectangular, have slightly convex margins, slightly constricted bases and rounded apices. Additionally, apical pinnules in Neuralethopteris weilii are wide, fused, and have loose venation, with lateral veins forked up to three times. Neuralethopteris smithsii shows also some similarity with the lower Bolsovian species Wagneropteris minima (see Álvarez-Vázquez and Cleal 2016). Both species have small, broadly oval to rounded pinnules with cordate bases and ovoid, well-individualized terminals. In addition, in the two species the lamina is thick, convex, and with similar vein density. However, the first anadromous and catadromous pinnules of Wagneropteris minima are smaller than the other laterals, thus allowing space for the characteristic intercalary pinnules that characterize Wagneropteris.

Stratigraphic and geographic distribution. Gillespie and Pfefferkorn (1979) recorded Neuralethopteris smithsii from upper Namurian (Yeadonian) to lower Westphalian A (= Langsettian) strata (middle Pocahontas to New River formations) in the Appalachian Basin. From the same area, Goubet et al. (2000) regarded Neuralethopteris smithsii as particularly abundant in the lower and middle part of the New River Formation (up to the Sewell coal interval), which is of middle Langsettian age.

Occurrence in the Maritime Provinces, Canada. CumberLAND BASIN (Nova ScOTIA): Bell (1944): locality 860 (GSC 5593 + GSC 5840 + GSC 5849 + GSC 5850 + GSC 5853 + GSC $5859+$ GS $5860+$ GSC $5955+$ GSC 5986 - paratypes of Sphenopteris minuscula + GSC 5857 - holotype of Sphenopteris minuscula); locality 1356 (four fragmentary specimens without catalogue number - cf.; it could be compared also with Neuralethopteris pocahontas); locality 1462 (two pieces without catalogue number - together with Pseudadiantites rhomboideus, Neuropteris sp. and Zeilleria frenzlii, which comprise six other pieces of the same locality); locality 1685 (three pieces without catalogue number). New BRUNSwICK: Bell (1944): locality 791 (poorly preserved specimen without catalogue number); locality 828 (three pieces, with fragmentary and poorly preserved specimens, without catalogue number - cf.; together with Calamites sp.); locality 831 (two pieces without catalogue number cf.; poorly preserved); locality 1359 (four pieces without catalogue number - fragmentary); locality 1369 (two pieces without catalogue number).
Occurrence in the United States. Alabama: Lesquereux (1879-84), White (1905), Butts (1926), Gastaldo (1985), Gillespie and Rheams (1985), Lyons et al. (1985), Goubet et al. (2000). Georgia: Lesquereux (1884), Gillespie and Crawford (1985). Tennessee: Lesquereux (1884). VIRGINIA: Blake et al. (2002). West Virginia: Lesquereux (1879-84), Jongmans (1937), Gillespie and Pfefferkorn (1979), Goubet et al. (2000), Blake et al. (2002).

\section{SUMMARY AND CONCLUSIONS}

The revision of Alethopteris and Neuralethopteris from lower Westphalian strata of Nova Scotia and New Brunswick, eastern Canada, has yielded eight species; three of these - Alethopteris bertrandii, Alethopteris cf. havlenae and Neuralethopteris pocahontas, - are cited for the first time in Canada. This revision was based on material reposited in the collections of the Geological Survey of Canada, Ottawa, recorded by Bell $(1944,1966)$, plus additional specimens stored in the collections of the New Brunswick Museum, Saint John, and in the Donald Reid Collection at the Joggins Fossil Institute.

Three species described by Dawson (1862, 1863, 1871), Pecopteris discrepans (= Pecopteris decurrens Dawson non Artis), Pecopteris ingens and Neuropteris selwynii, and one described by Bell (1944), Sphenopteris minuscula, are regarded as synonyms of European taxa. Although Neuropteris selwynii was described from Canadian material before its probable synonym Neuralethopteris schlehanii, the widespread use that has been made in the literature of the last name, combined with the fragmentary nature of Dawson's Neuropteris selwynii and its poor illustration and description, justify retaining Neuralethopteris schlehanii provisionally; and eventually, if the synonymy is confirmed, making a proposal to conserve the name Neuralethopteris schlehanii.

As with the other recently revised taxa (Lycopsida, Filicopsida, Annularia and Asterophyllites), Canadian taxa are basically the same as those recorded from strata of the same age in Europe. This newest revision enhances the striking resemblance of the Westphalian flora of the Canadian Maritime Provinces with that known from western Europe, as well as its paleogeographic proximity.

\section{ACKNOWLEDGEMENTS}

The late John Utting and the late Robert $\mathrm{H}$. Wagner are both gratefully acknowledged for the initiative to promote the revision of lower Westphalian floras in the Maritime Provinces of Canada. Jean Dougherty, formerly of Geological Survey of Canada, Ottawa, and Randall Miller, formerly of the New Brunswick Museum, Saint John, provided essential access and data regarding the fossil collections in their institutions. The late Donald Reid and the Joggins Fossil Centre kindly lent several specimens. The paper benefited from constructive comments and suggestions by the reviewers, 
Chris Cleal and Zbyněk Šimůnek. The helpful, well-focused suggestions and meticulous editing by Rob Fensome are gratefully acknowledged.

\section{REFERENCES}

Álvarez-Vázquez, C. 2019. Filicopsida from the lower Westphalian (Middle Pennsylvanian) of Nova Scotia and New Brunswick, Maritime Provinces, Canada. Atlantic Geology, 55, pp. 1-55. https://doi.org/10.4138/atlgeol.2019.001 Álvarez-Vázquez, C. and Cleal, C.J. 2016. Wagneropteris minima, a new medullosalean pteridosperm from the middle Westphalian (Middle Pennsylvanian) of the Peñarroya-Belmez-Espiel Coalfield (Córdoba province, SW Spain). Spanish Journal of Palaeontology, 31 (1), pp. 5-24. https://doi.org/10.7203/sjp.31.1.17119

Álvarez-Vázquez, C. and Wagner, R.H. 2014. Lycopsida from the lower Westphalian (Middle Pennsylvanian) of the Maritime Provinces, Canada. Atlantic Geology, 50, pp. 167-232. https://doi.org/10.4138/atlgeol.2014.011

Álvarez-Vázquez, C. and Wagner, R.H. 2017. A revision of Annularia and Asterophyllites species from the lower Westphalian (Middle Pennsylvanian) of the Maritime Provinces, Canada. Atlantic Geology, 53, pp. 17-62. https://doi.org/10.1088/1475-7516/2017/10/002

Arnold, C.A. 1934. A preliminary study of the fossil flora of the Michigan Coal Basin. Contributions from the Museum of Paleontology, University of Michigan, 4 (11), pp. 77-203.

Arnold, C.A. 1935. Observations on Alethopteris grandifolia Newberry and its seeds. Contributions from the Museum of Paleontology, University of Michigan, 4 (15), pp. 279-282.

Arnold, C.A. 1937. The seeds of Alethopteris, and other pteridosperms from North America. Compte Rendu $2^{\mathrm{e}}$ Congrès Congrès International de Stratigraphie et de Géologie du Carbonifère, Heerlen 1935, 1, pp. 41-45.

Arnold, C.A. 1941. Some Paleozoic plants from central Colorado and their stratigraphic significance. Contributions from the Museum of Paleontology, University of Michigan, 6 (4), pp. 59-70.

Arnold, C.A. 1947. An introduction to paleobotany. McGraw-Hill Book Company, New York, 433 p.

Arnold, C.A. 1949. Fossil flora of the Michigan Coal Basin. Contributions from the Museum of Paleontology, University of Michigan, 7 (9), pp. 131-269.

Artis, E.T. 1825. Antediluvian phytology, as illustrated by a collection of the fossil remains of plants peculiar to the coal formation of Great Britain. London, xiii $+24 \mathrm{p}$. https://doi.org/10.5962/bhl.title.119718

Bailey, L.W. 1865. Observations on the geology of southern New Brunswick, made principally during the summer of 1864 by Prof. L.W. Bailey, Messrs. Geo. F. Matthew, and C.F. Hartt, prepared and arranged, with a geological map. G.E. Fenety, Fredericton, 185 p.

Bashforth, A., Cleal, C.J., Gibling, M.R., Falcon-Lang, H.J., and Miller, R.F. 2014. Paleoecology of Early Pennsylvanian vegetation on a seasonally dry tropical landscape (Tynemouth Creek Formation, New Brunswick, Canada). Review of Palaeobotany and Palynology, 200, pp. 229-263. https://doi.org/10.1016/j.revpalbo.2013.09.006

Basson, P.W. 1968. The fossil flora of the Drywood Formation of southwestern Missouri. University of Missouri Studies, 44, pp. 1-170.

Bell, W.A. 1938. Fossil flora of Sydney Coalfield, Nova Scotia. Canada Department of Mines and Resources, Mines and Geology Branch, Geological Survey, Memoir 215, pp. 1-334. https://doi.org/10.4095/101646

Bell, W.A. 1944. Carboniferous rocks and fossil floras of northern Nova Scotia. Canada Department of Mines and Resources, Mines and Geology Branch, Geological Survey, Memoir 238, pp. 1-119. https://doi.org/10.4095/119859

Bell, W.A. 1962. Flora of Pennsylvanian Pictou Group of New Brunswick. Geological Survey of Canada, Department of Mines and Technical Surveys, Bulletin 87, pp. 1-71. https://doi.org/10.4095/100605

Bell, W.A. 1966. Illustrations of Canadian fossils. Carboniferous plants of eastern Canada. Geological Survey of Canada, Department of Mines and Technical Surveys, Paper 66-11, pl. I-XXXVI. https://doi.org/10.4095/100977

Bertrand, P. 1932. Bassin houiller de la Sarre et de la Lorraine. I. Flore fossile. $2^{\text {me }}$ fascicule. Aléthoptéridées. Études des Gîtes Minéraux de la France, Service de Topographies Souterraines. Text: pp. 65-107; Atlas: pl. XXXI-LX.

Blake, B.M. 1997. Revised lithostratigraphy and megafloral biostratigraphy of the New River and Kanawha formations (Pottsville Group: Lower and Middle Pennsylvanian) in southern West Virginia. Unpublished M.Sc. Thesis, West Virginia University, Morgantown, pp. 1-149.

Blake, B.M., Cross, A.T., Eble, C.F., Gillespie, W.H., and Pfefferkorn, H.W. 2002. Selected plant megafossils from the Carboniferous of the Appalachian region, eastern United States: geographic and stratigraphic distribution. In Carboniferous and Permian of the World. Proceedings XIV International Congress Carboniferous and Permian Stratigraphy, Calgary, Alberta 1999. Edited by L.V. Hills, C.M. Henderson, and E.W. Bamber. Canadian Society of Petroleum Geologists, Memoir 19, pp. 259-335.

Boulay, N. 1876. Le terrain houiller du Nord de la France et ses végétaux fossiles. Thèse de Géologie, Faculté des Sciences de Caen, Imprimérie Lefebvre-Ducrocq, Lille, 74 p.

Bouroz, A. 1956. Alethopteris Bertrandi nov. sp. du Westphalien $\mathrm{C}$ du Pas-de-Calais. Annales de la Société géologique du Nord, 75 (1955), pp. 137-143.

Brongniart, A. 1822. Sur la classification et la distribution des végétaux fossiles en général, et sur ceux des terrains de sédiment supérieur en particulier. Mémoires Muséum d'Histoire naturelle de Paris, 8, pp. 203-348.

Brongniart, A. 1828. Prodrome d'une histoire des végétaux fossiles. Paris and Strasbourg, F.G. Levrault, 225 p. https:// doi.org/10.5962/bhl.title.62840

Brongniart, A. 1831. Histoire des végétaux fossiles, ou recherches botaniques et géologiques sur les végétaux 
renfermés dans les diverses couches du globe. Texte, $\mathrm{n}^{\circ} 5$ : pp. 209-248; 6; Atlas: I - pl. 1-166. Facsimile Edition W. Junk, Berlin (1915).

Brongniart, A. 1833. Histoire des végétaux fossiles, ou recherches botaniques et géologiques sur les végétaux renfermés dans les diverses couches du globe. Texte, $\mathrm{n}^{\circ} 7$ : pp. 265-288; Atlas: I - pl. 1-166. Facsimile Edition W. Junk, Berlin (1915).

Brongniart, A. 1834. Histoire des végétaux fossiles, ou recherches botaniques et géologiques sur les végétaux renfermés dans les diverses couches du globe. Texte, $\mathrm{n}^{\circ} 8: \mathrm{pp}$. 289-312; Atlas: I - pl. 1-166. Facsimile Edition W. Junk, Berlin (1915).

Brongniart, A. 1874. Étude sur les graines fossiles trouvées à l'état silicifié dans le terrain houiller de Saint-Étienne. Annales Sciences naturelles, Botanique, série 5, pp. 234-265.

Brousmiche Delcambre, C., Mercier, D., and Coquel, R. 1996. Révision de la flore carbonifère du Briançonnais. Implications stratigraphiques. Ière partie: vallée de la $\mathrm{Du}$ rance au sud de Briançon. Palaeontographica, Abteilung B, 239 (4-6), pp. 77-107.

Brousmiche Delcambre, C., Mercier, D., and Coquel, R. 1998. Révision de la flore carbonifère du Briançonnais. Implications stratigraphiques. Partie II: Le Nord de Briançon, de la vallée de la Guisane à celle de la Clarée. Palaeontographica, Abteilung B, 248 (4-6), pp. 87-125.

Buisine, M. 1961. Contribution à létude de la flore du terrain houiller. Les Aléthoptéridées du Nord de la France. I. Flore fossile, $4^{\mathrm{e}}$ fascicule. Études Géologiques pour l'Atlas de Topographie Souterraine, Service Géologique des H.B.N.P.C. Texte: pp. 1-317. Atlas: pl. I-LXXIV.

Bunbury, C.J.F. 1847. On fossil plants from the Coal Formation of Cape Breton. Quarterly Journal of the Geological Society, London, 3, pp. 423-438. https://doi.org/10.1144/ GSL.JGS.1847.003.01-02.44

Butts, C. 1926. The Paleozoic rocks. In Geology of Alabama. Edited by G.I. Adams, C. Butts, L.W. Stephenson, and W. Cooke. Geological Survey of Alabama, Special Report 14, pp. 206-229.

Calder, J.H., Gibling, M.R., Scott, A.C., Davies, S.J., and Hebert, B.L. 2006. A fossil lycopsid forest succession in the classic Joggins section of Nova Scotia: paleoecology of a disturbance-prone Pennsylvanian wetland. Geological Society of America, Special Paper 399, pp. 169-195. https://doi.org/10.1130/2006.2399(09)

Canright, J.E. 1959. Fossil plants of Indiana. Indiana Department of Conservation, Geological Survey, Report of Progress, 14, pp. 1-45.

Cleal, C.J. and Shute, C.H. 1995. A synopsis of neuropteroid foliage from the Carboniferous and Lower Permian of Europe. Bulletin of the Natural History Museum London, Geology Series, 51 (1), pp. 1-52.

Cleal, C.J. and Shute, C.H. 2003. Systematics of the Late Carboniferous medullosalean pteridosperm Laveineopteris and its associated Cyclopteris leaves. Palaeontology, 46 (2), pp. 353-411. https://doi.org/10.1111/1475-4983.00303

Cleal, C.J., Shute, C.H., and Zodrow, E.L. 1990. A revised taxonomy for Palaeozoic neuropterid foliage. Taxon, 39 (3), pp. 486-492. https://doi.org/10.2307/1223109

Cleal, C.J., Fraser, H.E., Lazarus, M., and Dannell, G. 2009. The forests before the flood: the palaeobotanical contributions of Edmund Tyrell Artis (1789-1847). Earth Sciences History, 28 (2), 245-275. https://doi.org/10.17704/ eshi.28.2.31w8363563403478

Coquel, R. and Laveine, J.P. 1979. Alethopteris jankii nov. sp., du Westphalien C-D du Nord de la France. Annales de la Société géologique du Nord, 98, 123-126.

Corsin, P. 1932. Guide paléontologique dans le terrain houiller du Nord de la France. Travaux et Mémoires de l'Université de Lille, 5, pp. 1-44.

Corsin, P. 1960. Classification des ptéridophytes et des ptéridospermophytes du Carbonifère. Bulletin de la Société géologique de France, Série 7, 2, pp. 566-572.

Cremer, L. 1893. Über die Fossilen Farne des Westfälischen Carbons und ihre Bedeutung für eine Gliedernung des letzteren. Mitteilungen aus dem geologischen Museum der Westfälischen Berggewerkschaftskasse, 1, pp. 1-49.

Crookall, R. 1929. Coal Measure plants. Edward and Co Publishers, London, $80 \mathrm{p}$.

Crookall, R. 1932. The relative value of fossil plants in the stratigraphy of the Coal Measures. Memoirs and Proceedings of the Manchester Literary and Philosophical Society, 76 (1931-32), pp. 91-122.

Crookall, R. 1955. Fossil plants of the Carboniferous rocks of Great Britain. (Second section.) Memoirs of the Geological Survey of Great Britain, Palaeontology, 4 (1), pp. 1-84, pl. I-XXIV.

Crookall, R. 1959. Fossil plants of the Carboniferous rocks of Great Britain. (Second Section.) Memoirs of the Geological Survey of Great Britain, Palaeontology, 4 (2), pp. 85-216, pl. XXV-LVIII.

Crookall, R. 1976. Fossil plants of the Carboniferous rocks of Great Britain. (Second section.) Memoirs of the Geological Survey of Great Britain, Palaeontology, 4 (7), pp. 841-956, pl. CLX-CLXXIII.

Cross, A.T., Gillespie, W.H., and Taggart, R.E. 1996. Upper Paleozoic vascular plants. Chapter 23. In Fossils of Ohio. Department of Natural Resources, Division of Geological Survey, Bulletin 70, pp. 396-479.

Dawson, J.W. 1862. On the flora of the Devonian Period in north-eastern America. Quarterly Journal of the Geological Society of London, 18, pp. 296-330. https://doi. org/10.1144/GSL.JGS.1862.018.01-02.42

Dawson, J.W. 1863. Further observations on the Devonian plants of Maine, Gaspé, and New York. Quarterly Journal of the Geological Society of London, 19, pp. 458-469. https://doi.org/10.1144/GSL.JGS.1863.019.01-02.41

Dawson, J.W. 1868. Acadian geology. The geological structure, organic remains, and mineral resources of Nova Scotia, New Brunswick, and Prince Edward Island. London, 694 p. https://doi.org/10.5962/bhl.title.38560

Dawson, J.W. 1871. The fossil plants of the Devonian and Upper Silurian formations. Geological Survey of Canada, Report, 92 p. https://doi.org/10.4095/216073 
Dijkstra, S.J. and Amerom, H.W.J. van 1981. Fossilium Catalogus. II: Plantae. Pars 88 (43). Filicales, Pteridospermae, Cycadales. 2. Supplement, A-C. Kluger Publications, Amsterdam, pp. 1-143.

Dijkstra, S.J. and Amerom, H.W.J. van 1983. Fossilium Catalogus. II: Plantae. Pars 90 (45). Filicales, Pteridospermae, Cycadales. 2. Supplement, L-O. Kluger Publications, Amsterdam, pp. 293-460.

Dilcher, D.L. and Lott, T.A. 2005. Atlas of Union Chapel mine fossil plants. In Pennsylvanian footprints in the Black Warrior Basin of Alabama. Edited by R.J. Buta, A.K. Rindsberg, and D.C. Kopaska-Merkel. Alabama Paleontological Society, Monograph, 1, pp. 339-365.

Dilcher, D.L., Lott, T.A., and Axsmith, B.J. 2005. Fossil plants from the Union Chapel mine, Alabama. In Pennsylvanian footprints in the Black Warrior Basin of Alabama. Edited by R.J. Buta, A.K. Rindsberg, and D.C. Kopaska-Merkel. Alabama Paleontological Society, Monograph, 1, pp. 153168.

Ettingshausen, C. von 1852. Die Steinkohlenflora von Stradonitz in Böhmen. Abhandlungen Kaiserlich-Königlichen Geologischen Reichsanstalt, 2 (3), pp. 1-13.

Falcon-Lang, H.J. 2006. Vegetation ecology of Early Pennsylvanian alluvial fan and piedmont environments in southern New Brunswick, Canada. Palaeogeography, Palaeoclimatology, Palaeoecology, 233, pp. 34-50. https:// doi.org/10.1016/j.palaeo.2005.09.005

Fontaine, M. and White, I.C. 1880. The fossil flora of the Upper Carboniferous or Permian in West Virginia and south-west Pennsylvania. Second Geological Survey of Pennsylvania: Report of Progress PP, pp. 1-143. https:// doi.org/10.5962/bhl.title.100048

Franke, F. 1912. Alethopteris. In H. Potonié (coord.). Abbildungen und Beschreibungen fossiler Pflanzen-Reste, Lieferun VIII, 158, pp. 1-13.

Frech, F. 1880. Lethaea Geognostica. Handbuch der Erdgeschichte mit Abbildungen der für die Formationen bezeichnendsten Versteinerungen. Heraugegeben von Geologen unter Redaktion von Fritch Frech. Stuttgart, Schweitzerbartsche Verlag, Textband I, Lieferung 1, 324 p.

Gastaldo, R.A. 1985. Upper Carboniferous paleoecological reconstructions: observations and reconsiderations. Compte Rendu $10^{\mathrm{e}}$ Congrès International de Stratigraphie et de Géologie du Carbonifère, Madrid 1983, 2, pp. 281-296.

Gillespie, W.H. and Crawford, T.J. 1985. Plant megafossils from the Carboniferous of Georgia, U.S.A. Compte Ren$\mathrm{du} 10^{\mathrm{e}}$ Congrès International de Stratigraphie et de Géologie du Carbonifère, Madrid 1983, 2, pp. 247-256.

Gillespie, W.H. and Pfefferkorn, H.W. 1976. Plant fossils in early and middle parts of the proposed Pennsylvanian System stratotype in West Virginia. Carboniferous stratigraphy of southwestern Virginia and southern West Virginia, Geological Society of America Field Trip Guidebook No. 3, pp. 1-6.

Gillespie, W.H. and Pfefferkorn, H.W. 1979. Distribution of commonly occurring plant megafossils in the proposed Pennsylvanian System stratotype. Ninth International Congress of Carboniferous Stratigraphy and Geology. Field Trip No. 1, AGI Selected Guidebook Series, No. 1, pp. 87-97.

Gillespie, W.H. and Pfefferkorn, H.W. 1986. Plant fossils of the New River Gorge, West Virginia. Proceedings of the West Virginia Academy of Science, Papers of the Fifty-Ninth Annual Session, 56 (2, 3, 4), pp. 124-135.

Gillespie, W.H. and Rheams, L.J. 1985. Plant megafossils from the Carboniferous of Alabama, U.S.A. Compte Ren$\mathrm{du} 10^{\mathrm{e}}$ Congrès International de Stratigraphie et de Géologie du Carbonifère, Madrid 1983, 2, pp. 191-202.

Gillespie, W.H., Latimer, I.S., and Clendening, J.A. 1966. Plant fossils of West Virginia. West Virginia Geological and Economic Survey, Educational Series, pp. 1-131.

Gillespie, W.H., Clendening, J.A., and Pfefferkorn, H.W. 1978. Plant fossils of West Virginia and adjacent areas. West Virginia Geological and Economic Survey, Educational Series ED-3A, pp. 1-172.

Gillespie, W.H., Crawford, T.J., and Waters, J.A. 1989. Plant fossils of the Pennsylvanian System of Georgia. 38 ${ }^{\text {th }}$ Annual Meeting, Southeastern Section, The Geological Society of America, Guidebook Addendum, pp. 1-13.

Göppert, H.R. 1836. Die Fossilen Farrnkräuter. Verhandlungen der Kaiserlichen Leopoldinisch-Carolinischen Akademie der Naturforscher, XVII Suppl., 486 p.

Gothan, W. 1906. Desmopteris integra. In Abbildungen und Beschreibungen fossiler Pflanzen-Reste. Edited by H. Potonié. Königlich Preussischen Geologischen Landesanstalt, IV-64, pp. 1-3.

Gothan, W. 1909. Lonchopteris. In Abbildungen und Beschreibungen fossiler Pflanzen-Reste. Edited by $\mathrm{H}$. Potonié. Königlich Preussischen Geologischen Landesanstalt, VI117, pp. 1-7.

Gothan, W. 1913. Die Oberschlesische Steinkohlenflora. I. Farne und farnähnliche Gewächse (Cycadofilices bezw. Pteridospermen). Abhandlungen der Königlichen Preussischen Geologischen Landesanstalt, (Neue Folge), 75, pp. 1-278. https://doi.org/10.5962/bhl.title.150544

Gothan, W. 1953. Die Steinkohlenflora der westlichen paralischen Steinkohlenreviere Deutschlands. Beihefte zum Geologischen Jahrbuch, 10, pp. 1-83.

Goubet, P., Pfefferkorn, H.W., and Gillespie, W.H. 2000. Neuralethopterids (trigonocarpalean pteridosperms) from the Early Pennsylvanian of eastern North America. PaleoBios, 20 (3), pp. 11-37.

Grand'Eury, C.1877. Mémoire sur la flore Carbonifère du Département de la Loire et du centre de la France. Étudiée aux trois points de vue botanique, stratigraphique et géognostique. Mémoires Académie des Sciences de l'Institut National de France, 24 (1), pp. 1-624.

Gropp, W. 1932. Über das Vorkommen von Lyginopteris (Sphenopteris) porubensis (Trapl) Gothan. Arbeiten Institut Paläobotanik Petrographie Brennsteine, 2 (2), 233239.

Gutbier, A. von 1835. Abdrücke und Versteinerungen des 
Zwickauer Schwarzkohlengebirges und seiner Umgebungen. Zwickau, Verlag G. Richter'schen Buchhandlung, 80 p. https://doi.org/10.5962/bhl.title.152878

Guthörl, P. 1958. Neue Funde von Lonchopteridium Gothan aus dem Saarkarbon. Journal of the Palaeontological Society of India, Lucknow. Birbal Sahni Memorial No, 2, pp. $35-42$.

Halle, T.G. 1933. The structure of certain fossil spore-bearing organs believed to belong to pteridosperms. Kungliche Svenska Vetenskaps Akademiens Handlingar, 12 (6), pp. 1-101.

Havlena, V. 1970. Representatives of the genus Mariopteris Zeiller in the strata between the seams 40 and 34 of the Ostrava-Karviná coal district in the Upper Silesian Basin. Věstník Ústředniho ústavu geologického, 45, pp. 45-48.

Havlena, V. 1984. Alethopterids of the middle and upper Namurian, Ostrava-Karviná coalfield. Časopis pro mineralogii a geologii, 29 (4), pp. 369-377.

Heer, O. 1877. Flora fossilis Helvetiae. Die vorweltliche Flora der Schweiz. Verlag von J. Wurster and Comp., Zürich, $182 \mathrm{p}$.

Janssen, R.E. 1939. Leaves and stems from fossil forests. A handbook of the paleobotanical collections in the Illinois State Museum. Illinois State Museum, Popular Science Series, $1,190 \mathrm{p}$.

Janssen, R.E. 1957. Leaves and stems from fossil forests. A handbook of the paleobotanical collections in the Illinois State Museum. Illinois State Museum, Popular Science Series, 1, 190 p. (Second printing).

Jennings, J.R. 1984. Distribution of fossil plant taxa in the Upper Mississippian and Lower Pennsylvanian of the Illinois Basin. Compte Rendu $9^{\mathrm{e}}$ Congrès International de Stratigraphie et Géologie du Carbonifère, Washington and Champaign-Urbana 1979, 2, pp. 301-312.

Jongmans, W.J. 1928. Stratigraphie van het Karboon in het algemeen en van Limburg in het bijzonder. Algemeen overzicht over het Zuid-Limburgsche Karboon. Mededeeling, 6, 1926-1928, pp. 525-590.

Jongmans, W.J. 1937. Comparison of the floral sucession in the Carboniferous of West Virginia with Europe. Compte Rendu $2^{e}$ Congrès Congrès International de Stratigraphie et de Géologie du Carbonifère, Heerlen 1935, 1, pp. 393415.

Jongmans, W.J. 1957. Fossilium Catalogus. II: Plantae. Pars 30 (3). Filicales, Pteridospermae, Cycadales. Ed. W. Junk, The Hague, pp. 89-178.

Jongmans, W.J. 1960. Die Karbonflora der Schweiz. Beiträge zur Geologischen Karte der Schweiz, Schweizerischen Geologischen Kommission, Neue Folge, 108, pp. 1-97.

Jongmans, W.J. and Dijkstra, S.J. 1961. Fossilium Catalogus. II: Plantae. Pars 45 (18). Filicales, Pteridospermae, Cycadales. Ed. W. Junk, The Hague, pp. 1597-1686.

Josten, K.-H. 1983. Die fossilen Floren im Namur des Ruhrkarbons. Fortschritte in der Geologie von Rheinland und Westfalen, Geologisches Landesamt Nordrhein-Westfalen, Krefeld, 31, pp. 1-327.

Josten, K.-H. and Amerom, H.W.J. van 2003. Die Flora des
Namur B aus Hagen-Vorhalle. Geologie und Paläontologie in Westfalen, 61, pp. 1-303.

Kidston, R. 1884. On the fructification of Zeilleria (Sphenopteris) delicatula, Sternb., sp.; with remarks on Urnatopteris (Sphenopteris) tenella, Brongt., and Hymenophyllites (Sphenopteris) quadridactylites, Gutbier, sp. Quarterly Journal of the Geological Society, London, 40, pp. 590598. https://doi.org/10.1144/GSL.JGS.1884.40.01-04.49

Kidston, R. 1888. On the fructification of two coal-measure ferns. Annals and Magazine of Natural History, Series B, 2, pp. 22-27. https://doi.org/10.1080/00222938809460871

Kidston, R. 1914. On the fossil flora of the Staffordshire coal fields. Part III. - The fossil flora of the Westphalian Series of the South Staffordshire Coal Field. Transactions of the Royal Society of Edinburgh, 50, part I (5), pp. 73-199. https://doi.org/10.1017/S0080456800017282

Kidston, R. 1924. Fossil plants of the Carboniferous rocks of Great Britain. Memoirs Geological Survey of Great Britain, Palaeontology, 2 (5) (1924), pp. 377-522.

Knight, J. 1985. The stratigraphy of the Stephanian rocks of the Sabero Coalfield, León (NW. Spain) and an investigation of the fossil flora. Part III. Systematic Palaebotany; Pecopterids. Palaeontographica, Abteilung B, 197 (1-3), pp. 1-80.

Langford, G. 1958. The Wilmington Coal Flora from a Pennsylvanian deposit in Will County, Illinois. Earth Science Club of Northern Illinois, Esconi Associates, Illinois, $360 \mathrm{p}$.

Laveine, J.-P. 1967. Contribution à létude de la flore du terrain houiller. Les neuroptéridées du bassin houiller du Nord de la France. Études géologiques pour l’atlas de topographie souterraine publiées par le Service Géologique des Houillères du Basin du Nord et du Pas-de-Calais. I. Flore fossile, $5^{\mathrm{e}}$ fascicule. Texte: pp. 1-338; Atlas: pl. A-P; I-LXXXIV.

Laveine, J.-P. 1986. The size of the frond in the genus Alethopteris Sternberg (Pteridospermopsida, Carboniferous). Geobios, 19 (1), pp. 49-56; https://doi.org/10.1016/ S0016-6995(86)80035-3

Laveine, J.-P., Coquel, R., and Loboziak, S. 1977. Phylogénie générale des calliptéridacées (Pteridospermopsida). Géobios, 10 (6), pp. 757-847. https://doi.org/10.1016/S00166995(77)80080-6

Laveine, J.-P., Belhis, A., Lemoigne, Y., and Zhang, S. 1992. Frond architecture in the genera Neuralethopteris Cremer, Alethopteris Sternberg and Lonchopteris Brongniart (Carboniferous pteridosperms). Revue de Paléobiologie, volume special, 6, pp. 149-166.

Leary, R.L. 1976. Inventory of the type and figured paleobotanical specimens in the Illinois State Museum. Illinois State Museum, Inventory of Geological Collections, 2 (2), pp. 1-64.

Leary, R.L. and Pfefferkorn, H.W. 1977. An Early Pennsylvanian flora with Megalopteris and Noeggerathiales from west-central Illinois. Illinois State Geological Survey, Circular 500, pp. 1-77. https://doi.org/10.5962/bhl. $\underline{\text { title. } 61520}$ 
Leggewie, W. and Schonefeld, W. 1957. Pteridophyten und Pteridospermen der Sprockhöveler (= Magerkohlen-) Schichten (Namur C). Palaeontographica, Abteilung B, 101, pp. 1-29.

Lesquereux, L. 1854. New species of fossil plants, from the anthracite and bituminous coal-fields of Pennsylvania; collected and described by Leo Lesquereux. With introductory observations by Henry Darwin Rogers. Boston Journal of Natural History, 6 (4), pp. 409-431.

Lesquereux, L. 1858. Fossil plants of the coal strata of Pennsylvania. In H.D. Rogers, The geology of Pennsylvania, 2 (2), pp. 835-884.

Lesquereux, L. 1879-1884. Description of the coal flora of the Carboniferous formation in Pennsylvania and throughout the United States. Second Geological Survey of Pennsylvania, Report of Progress. Text - I (1880): pp. 1-354; II (1880): pp. 355-694, i-lxiii, pl. LXXXVI, LXXXVII; III (1884): pp. 695-977, pl. LXXXVIII-CXI. Atlas (1879): pl. A, B; pl. I-LXXXV.

Lindley, J. and Hutton, W. 1831. The fossil flora of Great Britain; or, figures and descriptions of the vegetable remains found in a fossil state in this country. I, pp. 1-47, pl. 1-14. James Ridgway and Sons, London. https://doi. org/10.5962/bhl.title.149330

Lindley, J. and Hutton, W. 1835. The fossil flora of Great Britain; or, figures and descriptions of the vegetable remains found in a fossil state in this country. II, pp. 1-72, pl. 157-176. James Ridgway and Sons, London.

Lyons, P.C. and Sproule, R.G. 2018. The fossil flora and age of the Wamsutta Formation red beds (Middle Pennsylvanian), Narragansett Basin, southeastern Massachusetts, USA and correlation with the Cumberland Group of the Maritime Provinces of Canada. Atlantic Geology, 54, pp. 315-334. https://doi.org/10.4138/atlgeol.2018.011

Lyons, P.C., Zeissner, C.R., Barwood, H.L., and Adinolfi, F.G. 1985. North American and European megafloral correlations with the upper part of the Pottsville Formation of the Warrior Coal Field; Alabama, U.S.A. Compte Rendu $10^{\text {e }}$ Congrès International de Stratigraphie et Géologie du Carbonifère, Madrid 1983, 2, pp. 203-245.

Matthew, G.F. 1910. Revision of the flora of the Little River Group No. II. Transactions of the Royal Society of Canada, Third Series, 3 (4), pp. 77-113.

Miller, R.F. 1987. George Frederic Matthew (1837-1923). Victorian Science in Saint John. New Brunswick Museum News, August-September 1987, pp.3-26.

Miller, R.F. and Buhay, D.N. 1988. The Steinhammer Club: geology and a foundation for a natural history society in New Brunswick. Geoscience Canada, 15 (3), pp. 221-226.

Moore, L.C., Wittry, J., and DiMichele, W.A. 2014. The Okmulgee, Oklahoma fossil flora, a Mazon Creek equivalent: spatial conservatism in the composition of Middle Pennsylvanian wetland vegetation over $1100 \mathrm{~km}$. Review of Palaeobotany and Palynology, 200, pp. 24-52. https://doi. org/10.1016/j.revpalbo.2013.08.002

Newberry, J.S. 1853. Fossil plants from the Ohio coal basin. Annals of Science, Cleveland, 5 (8), pp. 95-97.
Newberry, J.S. 1873. Descriptions of fossil plants from the coal measures of Ohio. Geological Survey of Ohio, Paleontology, I, pp. 359-385.

Novik, K. 1947. Classification of Carboniferous Pteridospermae. Doklady Akademii Nauk S.S.S.R., 58 (2), pp. 277-279 (in Russian).

Oleksyshyn, J. 1982. Fossil plants from the anthracite coal fields of eastern Pennsylvania. Pennsylvania Geological Survey, General Geology Report 72, pp. 1-157.

Pfefferkorn, H.W. and Gillespie, W.H. 1977. Plant fossils in the proposed Pennsylvanian System stratotype. In A field guide to proposed Pennsylvania System stratotype, West Virginia. Edited by K.J. Englund, H.H. Arndt, W.H. Gillespie, T.W. Henry, and H.W. Pfefferkorn. Annual AAPG/ SEPM Convention, Washington, Pre-Meeting Field Trip, June 1977, pp. 21-26.

Pfefferkorn, H.W. and Gillespie, W.H. 1981. Biostratigraphic significance of plant megafossils near the MississippianPennsylvanian boundary in southern West Virginia and southwestern Virginia. In GSA Cincinnati '81 field trip guidebooks. volume I: stratigraphy, sedimentology. $E d-$ ited by T.G. Roberts. American Geological Institute, pp. 159-164.

Potonié, H. 1893. Ueber das Rothliegende des Thüringer Waldes. Theil II: Die Flora des Rothliegenden von Thüringen. Abhandlungen der Königlich Preussischen geologischen Landesanstalt. Neue Folge 9, pp. 1-298.

Purkyňová, E. 1970. Die Unternamurflora des Beckens von Horní Slezsko (ČSSR). Paläontologische Abhandlungen, Abteilung B, Paläobotanik, III (2), pp. 129-268.

Purkyňová, E. 1990. K biostratigrafii karbonu v doubravských vrstvách hornoslezské černouhelné pánve. Časopis Slezského Muzea Opava (A), 39, 213-224.

Read, C.B. 1934. A flora of Pottsville age from the Mosquito Range, Colorado. Geological Survey, Professional Paper 185-D, pp. 79-96. https://doi.org/10.3133/pp185D

Read, C.B. and Mamay, S.H. 1964. Upper Paleozoic floral zones and floral provinces of the United States. Shorter contributions to general geology. Geological Survey Professional Paper 454-K, pp. K1-K35. https://doi. org/10.3133/pp454K

Rothwell, G.W. and Eggert, D.A. 1986. A monograph of Dolerotheca Halle, and related complex permineralised medullosan pollen organs. Transactions Royal Society of Edinburgh, 77, pp. 47-79. https://doi.org/10.1017/ S0263593300099995

Sauveur, M. 1848. Végétaux fossiles des terrains houillers de la Belgique. Académie Royale des Sciences, des Lettres et des Beaux-Arts de Belgique, pl. I-XXXVI.

Schimper, W.P. 1869. Traité de paléontologie végétale ou la flore du monde primitif dans ses rapports avec les formations géologiques et la flore du monde actuel. Texte - I: pp. 1-738. J.B. Baillière et Fils, Paris. https://doi. org/10.5962/bhl.title.60570

Schlotheim, E.F. von 1820. Die Petrefactenkunde auf ihrem jetztigen Standpunkte, durch die Beschreibung seiner Sammlung versteinerter und fossiler Überreste des Thier- 
und Pflanzenreichs der Vorwelt erläutert. Gotha, i-lxii (Einleitung), pp. 1-437, pl. I-XXXVI.

Šimůnek, Z. 1996. Carboniferous alethopterids of the Karviná and Žacléř formations (Czech Republic). Sborník geologických věd, Paleontologie, 33, pp. 5-37.

Solovieva, M.N., Gubareva, V.S., Ivanova, E.A., Fissunenko, O.P., Shcherbakov, O.A., and Einor, O.L. 1996. Moscovian Stage. In The Carboniferous of the World. III. The former USSR, Mongolia, Middle Eastern Platform, Afghanistan, and Iran. Edited by R.H. Wagner, C.F. Winkler Prins, and L.F. Granados. International Union of Geological Sciences Publication 33, pp. 69-98. Instituto Geológico y Minero de España, Madrid.

Sternberg, K. von 1821. Versuch einer geognostisch-botanischer Darstellung der Flora der Vorwelt. I - 1: pp. 1-24, Tafn I-XIII.

Sternberg, K. von 1823. Versuch einer geognostisch-botanischer Darstellung der Flora der Vorwelt. I - 2: pp. 1-33, Tafn XIV-XXVI.

Sternberg, K. von 1824. Versuch einer geognostisch-botanischer Darstellung der Flora der Vorwelt. I - 3: pp. 1-40, Tafn XXVII-XXXIX.

Sternberg, K. von 1825. Versuch einer geognostisch-botanischer Darstellung der Flora der Vorwelt. I - 4: pp. 1-48, Tafn XL-LIX, Tafn A-E.

Stockmans, F. 1933. Les neuroptéridées des bassins houillers belges (première partie). Mémoires du Musée Royal d'Histoire Naturelle de Belgique, 57, pp. 1-61.

Stockmans, F. and Willière, Y. 1951. Quelques végétaux namuriens et westphaliens du Charbonnage d'Aiseau-Presle. In Étude géologique du Bassin Houiller de Charleroi. La concession Tergnée-Aiseau-Presle (première partie). Edited by W. van Leckwyck. Association pour l'étude de la Paléontologie et de la Stratigraphie houillères, 9, pl. A-D.

Stockmans, F. and Willière, Y. 1952a-1953. Végétaux namuriens de la Belgique. Association pour l'Étude de la Paléontologie et de la Stratigraphie houillères, 13. Texte (1953): pp. 1-382. Atlas (1952): pl. I-LVII.

Stockmans, F. and Willière, Y. 1952b. Quelques végétaux namuriens de la Galerie de Ben. In Étude géologique du Gisement Houiller d'Andenne-Huy. Edited by W. van Leckwyck, F. Demanet, Y. Willière and H. Chaudoir. Publications Association pour l'Étude de la Paléontologie et de la Stratigraphie Houillères, Bruxelles, 11, pl. A-F.

Stopes, M.C. 1914. The "Fern Ledges" Carboniferous flora of St. John, New Brunswick. Geological Survey of Canada, Memoir 41 (38 of Geological Series), pp. 1-142, pl. I-XXV. https://doi.org/10.5962/bhl.title.64206

Stur, D. 1877. Die Culm-Flora der Ostrauer und Waldenburger Schichten. Abhandlungen der Kaiserlichen-Königlichen Geologischen Reichsanstalt, 8, pp. 1-366, pl. I-XXVII (XVIII-XLIV).

Stur, D. 1883. Zur Morphologie und Systematik der Culmund Carbonfarne. Sitzberichte Königlichen Akademie der Wissenschaften, I Abtheilung, LXXXVIII, pp. 633$846(1-214)$.
Suckow, G.A. 1784. Beschreibung einiger merkwürdiger Abdrücke von der Art der sogenannten Calamiten. Acta Academiae Theodoro-Palatinae, 5, Pars Physica, pp. 166200.

Šusta, V. 1928. Stratigraphie des Ostrau-Karviner Steinkohlenreviers im Lichte der Paläontologie. In: Der Kohlenbergbau des Ostrau-Karviner Steinkohlenreviers (Direcktoren-Konferenz des Ostrau-Karviner Steinkohlenreviers in Mährisch Ostrau im Zehnten Jahre der Čechoslovakischen Republik), pp. 381-484.

Šusta, V. 1930. Neuropteris Larischi, n. sp. Sborník Přírodovědecké společnosti v Moravské Ostravě, pp. 3-6.

Taylor, T.N. and Kurmann, M. H. 1985. Boulayatheca, the new name for the seed fern pollen organ Boulaya Carpentier. Taxon, 34 (4), pp. 666-667. https://doi. org/10.2307/1222209

Tenchov, Y.G. 1977. Flora und Biostratigraphie des Oberkarbons im Svoge-Becken (VR Bulgarien). Schriftenreihe für Geologische Wissenschaften, Berlin, 7, pp. 1-163.

Tenchov, Y.G. and Cleal, C.J. 2010. Neuralethopteris foliage (Medullosales) in the Carboniferous of the Dobrudzha Coalfield, Bulgaria. Review of Palaeobotany and Palynology, 158, pp. 298-307. https://doi.org/10.1016/j.revpalbo.2009.10.001

Tidwell, W.D. 1967. Flora of Manning Canyon Shale. Part I: A lowermost Pennsylvanian flora from the Manning Canyon Shale, Utah, and its stratigraphic significance. Brigham Young University Geology Studies, 14, pp. 1-66.

Unger, F. 1850. Genera et species plantarum fossilium. Sumptibus Academiae Caesareae Scientiarium. W. Braumüller, Vindobonae, 628 p. https://doi.org/10.5962/ bhl.title. 26645

Wagner, R.H. 1961. Some Alethopterideae from the South Limburg Coalfield. Mededelingen Geologische Stichting, Nieuwe Serie, 14, pp. 5-13.

Wagner, R.H. 1963. Sur les Callipteridium du Westphalien supérieur et du Stéphanien. Comptes rendus de l'Académie des Sciences, 257, pp. 719-721.

Wagner, R.H. 1965. Stephanian B flora from the Ciñera-Matallana Coalfield (León) and neighbouring outliers. III. Callipteridium and Alethopteris. Notas y Comunicaciones del Instituto Geológico y Minero de España, 78, pp. 5-69.

Wagner, R.H. 1968. Upper Westphalian and Stephanian species of Alethopteris from Europe, Asia Minor and North America. Mededelingen Rijks Geologische Dienst, Serie C, III-1 (6), pp. 1-188.

Wagner, R.H. 1984. Megafloral Zones of the Carboniferous. Compte Rendu $9^{\mathrm{e}}$ Congrès Carbonifère, Washington-Urbana 1979, 2, pp. 109-134.

Wagner, R.H. 2001. The extrabasinal elements in lower Pennsylvanian floras of the Maritime Provinces, Canada: description of Adiantites, Pseudadiantites and Rhacopteridium. Revista Española de Paleontología, 16 (2), pp. 187-207.

Wagner, R.H. 2005a. Dicranophyllum glabrum (Dawson) Stopes, an unusual element of lower Westphalian floras in Atlantic Canada. Revista Española de Paleontología, 20 
(1), pp. 7-13.

Wagner, R.H. 2005b. Alethopteris lancifolia Wagner, a rare element of lower Westphalian "Fern Ledges" of Atlantic Canada. Revista Española de Paleontología, 20 (1), pp. 15-19.

Wagner, R.H. 2008. Laveineopteris polymorpha from the lower Westphalian (Langsettian) "Fern Ledges" at Saint John, New Brunswick, Canada, and comparison with Laveineopteris hollandica from Europe. Revista Española de Paleontología, 23 (2), pp. 139-156.

Wagner, R.H. and Álvarez-Vázquez, C. 2008. A revision of the lower Pennsylvanian Alethopteris lonchitica (auctorum) and its identity with Alethopteris urophylla. Revista Española de Paleontología, 23 (2), pp. 157-192.

Wagner, R.H. and Álvarez-Vázquez, C. 2010. The Carboniferous floras of the Iberian Peninsula: a synthesis with geological connotations. Review of Palaeobotany and Palynology, 162 (3), pp. 238-324. https://doi.org/10.1016/j. revpalbo.2010.06.005

Weiss, C.E. 1884. Beiträge zur fossilen Flora. III. Steinkohlen-Calamarien. II. Königlich Preussischen geologischen Landesanstalt, 5 (2), Text: pp. 87-290; Atlas: pl. I-XXVIII.

Weiss, E. 1870. Studien über Odontopteridem. Zeitschrift der Deutschen Geologischen Gesellschaft, 22 (4), pp. 853-888.

White, D. 1899. Fossil flora of the Lower Coal Measures of Missouri. United States Geological Survey, Monographs, 37, pp. 1-467. https://doi.org/10.5962/bhl.title.38916

White, D. 1900. The stratigraphic succession of the fossil floras of the Pottsville Formation in the Southern Anthracite coal field, Pennsylvania. Twentieth Annual Report United States Geological Survey, 1898-1899, Part 2 General Geology and Paleontology, pp. 749-918. https:// doi.org/10.5962/bhl.title.7601

White, D. 1901. The Canadian species of the genus Whittleseya and their systematic relations. The Ottawa Naturalist, 15 (4), pp. 98-110.

White, D. 1905. Fossil plants of the group Cycadofilices. Smithsonian Miscellaneous Collection, 47, pp. 377-390.

Williams, L. 1937. A study of Neuropteris schlehani Stur. Journal of Paleontology, 11 (5), pp. 462-465.

Wittry, J. 2006. The Mazon Creek fossil flora. Earth Science Club of Northern Illinois, Esconi Associates, Illinois, pp. $1-154$.

Wood, J.M. 1963. The Stanley Cemetery flora (early Pennsylvanian) of Greene County, Indiana. Indiana Department of Conservation, Geological Survey, Bulletin 29, pp. $1-73$.

Zalessky, M.D. 1937. Sur quelques végétaux fossiles nouveaux des terrains Carbonifère et Permien du Bassin du Donetz. In Problems of Paleontology, II-III. Edited by A. Hartmann-Weinberg. Laboratory of Paleontology, Moscow University, pp. 155-193.

Zeiller, R. 1879. Végétaux fossiles du terrain houiller de la France. Explication de la Carte Géologique detaillée de la France, Tome Quatrième, Seconde Partie, pp. 1-185.
Zeiller, R. 1883. Fructifications de fougères du terrain houiller. Annales Sciences naturelles, Paris, Botanique, $6^{e}$ série, 17, pp. 130-143.

Zeiller, R. 1886-1888. Bassin houiller de Valenciennes. Description de la flore fossile. Études des Gîtes Mineraux de la France. Texte (1888): 1-729. Atlas (1886): pl. I-XCIV.

Zodrow, E.L. and Cleal, C.J. 1998. Revision of the pteridosperm foliage Alethopteris and Lonchopteridium (Upper Carboniferous), Sydney Coalfield, Nova Scotia, Canada. Palaeontographica, Abteilung B, 247 (3-6), pp. 65-122.

\section{APPENDIX}

\section{List of names of genera, species and infraspecific taxa cited herein, with authorships}

Alethopteris Sternberg 1825

Alethopteris bertrandii Bouroz 1956

Alethopteris corsinii Buisine 1961

Alethopteris davreuxii (Brongniart 1828) Göppert 1836

Alethopteris decurrens (Artis 1825) Frech 1880

Alethopteris decurrens var. gracillima Crookall 1955

Alethopteris densinervosa Wagner 1968

Alethopteris discrepans (Dawson 1863) Dawson in Bailey 1865

Alethopteris edwardsii Stockmans and Willière 1952a

Alethopteris evansii Lesquereux 1884

Alethopteris gracillima Boulay 1876

Alethopteris grandifolia Newberry 1873

Alethopteris grandinii (Brongniart 1828) Göppert 1836

Alethopteris havlenae Šimůnek 1996

Alethopteris helenae Lesquereux 1879

Alethopteris integra (Gothan 1906) Kidston 1914

Alethopteris jankii Coquel and Laveine 1979

Alethopteris lancifolia Wagner 1961

Alethopteris lesquereuxii Wagner 1968

Alethopteris lonchitica Schlotheim 1820 ex Sternberg 1825

Alethopteris lonchitica forma serlii Brongniart 1828

Alethopteris lonchitifolia Bertrand 1932

Alethopteris missouriensis White 1899

Alethopteris pseudograndinioides Zodrow and Cleal 1998

Alethopteris scalariformis Bell 1938

Alethopteris serlii (Brongniart 1828) Göppert 1836

Alethopteris serlii forma lonchitifolia Bertrand 1932

Alethopteris solutifolia Josten and Amerom 2003

Alethopteris sullivantii (Lesquereux 1858) Fontaine and

White 1880

Alethopteris tectensis Stockmans and Willière 1952a

Alethopteris urophylla (Brongniart 1834) Göppert 1836

Alethopteris valida Boulay 1876

Alethopteris westphalensis Wagner 1968

Annularia Sternberg 1821

Annularia ramosa Weiss 1884

Asterophyllites Brongniart 1822

Aulacotheca Halle 1933

Bergeria dilatata (Lindley and Hutton 1831) Álvarez- 
Vázquez and Wagner 2014

Bernaultia Rothwell and Eggert 1986

Boulayatheca Taylor and Kurmann 1985

Calamites Suckow 1784

Calamites carinatus Sternberg 1824

Calamites cistii Brongniart 1828

Callipteridium Weiss 1870

Callipteridium sullivanti (Lesquereux 1854) Weiss 1870

Cordaianthus Grand'Eury 1877

Cordaites Unger 1850

Crossotheca pinnatifida (Gutbier 1835) Potonié 1893

Diaphorodendron decurtatum (Dawson 1868) Álvarez-

Vázquez and Wagner 2014

Eusphenopteris Gothan 1913 ex Novik 1947

Filicites decurrens Artis 1825

Johannophyton Matthew 1910

Johannophyton discrepans (Dawson in Bailey 1865) Matthew 1910

Laveineopteris rarinervis (Bunbury 1847) Cleal et al. 1990

Lepidostrobophyllum lanceolatum (Lindley and Hutton 1831) Bell 1938

Lonchopteridium (Gothan 1909) Guthörl 1958

Lonchopteris Brongniart 1828

Lyginopteris hoeninghausii (Brongniart 1828) Gropp 1932

Margaritopteris Gothan 1913

Margaritopteris conwayi (Lindley and Hutton 1835) Crookall 1929

Margaritopteris pseudocoemansii Gothan 1913

Neuralethopteris Cremer 1893

Neuralethopteris biformis (Lesquereux 1880) Goubet et al. 2000

Neuralethopteris jongmansii Laveine 1967

Neuralethopteris larischii (Šusta 1930) Laveine 1967

Neuralethopteris pocahontas (White 1900) Goubet et al. 2000

Neuralethopteris rectinervis (Kidston 1888) Laveine 1967

Neuralethopteris schlehanii (Stur 1877) Cremer 1893

Neuralethopteris sergiorum Goubet et al. 2000

Neuralethopteris smithsii (Lesquereux 1879) Goubet et al. 2000

Neuralethopteris weilii Josten and Amerom 2003

Neuropteris (Brongniart 1822) Sternberg 1825

Neuropteris bulupalganensis Zalessky 1937

Neuropteris dluhoschii Stur 1877

Neuropteris elrodii Lesquereux 1880

Neuropteris heterophylla (Brongniart 1822) Sternberg 1825

Neuropteris lata Tenchov 1977

Neuropteris longifolia Tenchov 1977

Neuropteris microphylla Brongniart 1831

Neuropteris multivenosa Purkyňová 1970
Neuropteris parvifolia Stockmans 1933

Neuropteris pocahontas White 1900

Neuropteris pocahontas var. inaequalis White 1900

Neuropteris rarinervis Bunbury 1847

Neuropteris rectinervis Kidston 1888

Neuropteris rectinervis forma obtusa Tenchov 1977

Neuropteris schlehanii Stur 1877

Neuropteris schlehanoides Stockmans and Willière 1952a

Neuropteris selwynii Dawson 1871

Neuropteris smithsii Lesquereux 1879

Pachytesta Brongniart 1874

Paripteris gigantea (Sternberg 1823) Gothan 1953

Pecopteris aspera Brongniart 1828

Pecopteris decurrens Dawson 1862

Pecopteris discrepans Dawson 1863

Pecopteris ingens Dawson 1862

Pecopteris mantellii Brongniart 1833

Pecopteris multiformis Sauveur 1848

Pecopteris urophylla Brongniart 1834

Pseudadiantites rhomboideus (Ettingshausen 1852) Wagner 2001

Praecallipteridium Wagner 1963

Praecallipteridium jongmansii (Bertrand 1932) Wagner 1963

Remia pinnatifida (Gutbier 1835) Knight 1985

Renaultia Zeiller 1883

Rhacopteris Schimper 1869

Senftenbergia aspera (Brongniart 1828) Stur 1877

Sigillaria scutellata Brongniart 1822

Sphenophyllum Brongniart 1828

Sphenophyllum cuneifolium (Sternberg 1823) Zeiller 1879

Sphenopteris hollandica Gothan and Jongmans in Jongmans 1928

Sphenopteris minuscula Bell 1944

Sphenopteris nummularia Gutbier 1835

Sporangites acuminatus (Dawson 1862) Dawson 1871

Trigonocarpus Brongniart 1828

Wagneropteris minima Álvarez-Vázquez and Cleal 2016

Whittleseya Newberry 1853

Whittleseya brevifolia White 1901

Whittleseya concinna Matthew 1910

Whittleseya concinna var. arcta Matthew 1910

Whittleseya concinna var. lata Matthew 1910

Whittleseya dawsoniana White 1901

Whittleseya desiderata White 1901

Zeilleria avoldensis (Stur 1883) Kidston 1884

Zeilleria frenzlii (Stur 1883) Kidston 1884

Zeilleria hymenophylloides Kidston 1924

Editorial responsibility: Robert A. Fensome 